\title{
amoA-encoding archaea and thaumarchaeol in the lakes on the northeastern Qinghai-Tibetan Plateau, China
}

\section{Jian Yang 1,2, Hongchen Jiang 1,2 *, Hailiang Dong ${ }^{1,3}{ }^{*}$, Huanye Wang ${ }^{4}$, Geng Wu ${ }^{1}$, Weiguo Hou ${ }^{5}$, Weiguo Liu ${ }^{4}$, Chuanlun Zhang ${ }^{6,7}$, Yongjuan Sun ${ }^{2}$ and Zhongping Lai ${ }^{2}$}

\author{
' State Key Laboratory of Biogeology and Environmental Geology, China University of Geosciences, Wuhan, China \\ ${ }^{2}$ Key Lab of Salt Lake Resources and Chemistry, Qinghai Institute of Salt Lakes, Chinese Academy of Sciences, Xining, China \\ ${ }^{3}$ Department of Geology and Environmental Earth Science, Miami University, Oxford, OH, USA \\ ${ }^{4}$ State Key Laboratory of Loess and Quaternary Geology, Institute of Earth Environment, Chinese Academy of Sciences, Xi'an, China \\ ${ }^{5}$ State Key Laboratory of Biogeology and Environmental Geology, China University of Geosciences, Beijing, China \\ ${ }^{6}$ Department of Marine Sciences, University of Georgia, Athens, GA, USA \\ 7 State Key Laboratory of Marine Geology, Tongji University, Shanghai, China
}

\section{Edited by:}

Brian P. Hedlund, University of Nevada at Las Vegas, USA

\section{Reviewed by:}

Annika Mosier, University of California at Berkeley, USA

Emilio O. Casamayor, Spanish National Research Council, Spain

Brian B. Oakley, Agricultural Research Service, USA

\section{${ }^{*}$ Correspondence:}

Hongchen Jiang and Hailiang Dong, State Key Laboratory of Biogeology and Environmental Geology, China

University of Geosciences, 338 Lumo Road, Hongshan District, Wuhan,

Hubei Province 430074, China e-mail: jiangh@cug.edu.cn, hongchen.jiang@gmail.com; dongh@cug.edu.cn, dongh@miamioh.edu
All known ammonia-oxidizing archaea (AOA) belong to the phylum Thaumarchaeota within the domain Archaea. AOA possess the diagnostic amoA gene (encoding the alpha subunit of ammonia monooxygenase) and produce lipid biomarker thaumarchaeol. Although the abundance and diversity of amoA gene-encoding archaea (AEA) in freshwater lakes have been well-studied, little is known about AEA ecology in saline/hypersaline lakes. In this study, the distribution of the archaeal amoA gene and thaumarchaeol were investigated in nine Qinghai-Tibetan lakes with a salinity range from freshwater to salt-saturation (salinity: $325 \mathrm{~g} \mathrm{~L}^{-1}$ ). The results showed that the archaeal amoA gene was present in hypersaline lakes with salinity up to $160 \mathrm{~g} \mathrm{~L}^{-1}$. The archaeal amoA gene diversity in Tibetan lakes was different from those in other lakes worldwide, suggesting Tibetan lakes (high elevation, strong ultraviolet, and dry climate) may host a unique AEA population of different evolutionary origin from those in other lakes. Thaumarchaeol was present in all of the studied hypersaline lakes, even in those where no AEA amoA gene was observed. Future research is needed to determine the ecological function of $A E A$ and possible sources of thaumarchaeol in the Qinghai-Tibetan hypersaline lakes.

Keywords: amoA gene, AEA, Thaumarchaeol, salinity, Qinghai-Tibetan lakes

\section{INTRODUCTION}

Microbial oxidation of ammonia to nitrite, the first step in nitrification, plays an important role in the global nitrogen cycle. This biogeochemical process is mainly carried out by two groups of microorganisms: ammonia-oxidizing bacteria (AOB) and ammonia-oxidizing archaea (AOA; Nicol and Schleper, 2006), which share a highly divergent homolog of ammonia monooxygenase. The amoA gene, encoding the alpha subunit of ammonia monooxygenase, has been widely exploited as a molecular biomarker to study $\mathrm{AOB}$ and $\mathrm{AOA}$ distributions in various environments (Stahl and de la Torre, 2012). However, it is unknown whether all archaea possessing the amoA gene are capable of ammonia oxidation. For example, the uncultivated marine sponge symbiont "Candidatus Cenarchaeum symbiosum" possess the amoA gene, but there is no evidence for ammonia oxidation (Preston et al., 1996). Accordingly, Dang et al. (2009) proposed a general name "amoA-encoding archaea (AEA)" for all amoA gene-carrying archaea, which are widely distributed in various ecosystems (Hatzenpichler, 2012; Stahl and de la Torre, 2012 and refs therein).

amoA-encoding archaea distributions are controlled by multiple environmental factors (Erguder et al., 2009), among which salinity has been shown to shape AEA diversity in estuaries and saline lakes (Mosier and Francis, 2008; Sahan and Muyzer, 2008; Hu et al., 2010). To date, the highest salinity at which archaeal amoA genes have been detected is 36.6 practical salinity units in the water column of the Sargasso Sea (Venter et al., 2004). Thus, it is still unclear whether AEA are present in higher salinity environments and how they respond to changes in salinity from freshwater to hypersaline (up to salt saturation) environments.

In addition to the amo $A$ gene, lipids are another type of functional biomarkers for studying AEA distribution in nature. All archaea synthesize a kind of membrane lipids known as isoprenoid glycerol dialkyl glycerol tetraethers (iGDGTs; Schouten etal., 2013), which were composed of an isoprenoid carbon skeleton ether bonded to a glycerol-moiety containing $0-4$ cyclopentane rings (corresponding to GDGT-0, GDGT-1, GDGT-2, GDGT-3, and GDGT-4, respectively; Pearson and Ingalls, 2013). Additionally, the GDGT "crenarchaeol," containing four cyclopentyl rings and one cyclohexyl ring was also detected in many marine and lacustrine environments (Castañeda and Schouten, 2011). Up to now, crenarchaeol was only found in the cell membranes of AOA isolates (de la Torre et al., 2008; Schouten et al., 2008; Pitcher et al., 2010), thus many studies proposed crenarchaeol as a characteristic biomarker of AOA (Pearson et al., 2004; Zhang et al., 2006; Pester et al., 2011; Pitcher et al., 2011a; Sinninghe Damsté et al., 2012). 
Originally, the AOA were thought to belong to the phylum Crenarchaeota on the basis of their 16S rRNA genes (Könneke et al., 2005). Subsequently, systematic comparison of 53 ribosomal proteins shared by Archaea, Eukarya, and the genomes of AOA isolates (i.e., Nitrosopumilus maritimus and Nitrososphaera gargensis) suggested that AOA belong to a separate phylum of the Archaea and should be classified as a new phylum proposed as Thaumarchaeota (Brochier-Armanet et al., 2008; Spang et al., 2010). In order to be consistent with the phylum Thaumarchaeota, crenarchaeol was renamed thaumarchaeol (Sinninghe Damsté et al., 2012). To date, thaumarchaeol has been detected in different environments, such as marine ecosystems (Sinninghe Damsté et al., 2002; Pitcher et al., 2011a), soils (Weijers et al., 2006), hot springs (Pearson et al., 2004, 2008; Zhang etal., 2006; Pitcher et al., 2009), and lakes (Castañeda and Schouten, 2011). To our knowledge, however, few studies have reported the presence and distribution of thaumarchaeol in hypersaline lakes where salinity is higher than that of seawater.

The Qinghai-Tibetan Plateau is the largest $\left(2 \times 10^{6} \mathrm{~km}^{2}\right)$ and highest (average $\sim 4500 \mathrm{~m}$ a.s.l.) plateau on the Earth. It contains thousands of saline/hypersaline lakes, which possess a broad range of environmental gradients such as salinity (from 0.1 to 426.3 $\mathrm{g} \mathrm{L}^{-1}$ ) and pH (5.4-10.2; Yang et al., 2004; Wu et al., 2006; Dong etal., 2010; Liu etal., 2012; Xiong etal., 2012). So the Qinghai-Tibetan lakes are ideal for assessing AEA diversity and community structure in response to environmental conditions (e.g., salinity). The objectives of this study were: (1) to investigate the abundance and diversity of AEA in Qinghai-Tibetan lakes with different salinities by using an integrated approach including lipids and amoA gene-based molecular analysis; (2) to assess how the AEA population correlates with environmental variables such as salinity and $\mathrm{pH}$; and (3) to determine whether thaumarchaeol can be found above the seawater salinity and how AEA respond to salinity change from freshwater to hypersaline.

\section{MATERIALS AND METHODS DESCRIPTION OF STUDY LAKES}

Nine lakes (Keluke Lake, Erhai Lake, Qinghai Lake, Tuosu Lake, Gahai Lake 1, Gahai Lake 2, Xiaochaidan Lake, Dongdabuxun Lake and Lake Chaka) on the Qinghai-Tibetan Plateau were selected for this study (Figure 1; Table 2). Keluke Lake is situated in the region of Delingha city. It has a surface area of $56.7 \mathrm{~km}^{2}$ with the maximum water depth of $13.3 \mathrm{~m}$ (Wang and Dou, 1998). Qinghai Lake is the largest saline lake in China, which is located in a structural intermontane depression at the northeastern corner of the Qinghai-Tibetan Plateau. It has an area of $4300 \mathrm{~km}^{2}$ and an average water depth of $19.2 \mathrm{~m}$ (Dong et al., 2006). Erhai Lake and Gahai Lake 1 are two daughter lakes of Qinghai Lake. Erhai Lake is a freshwater lake with a surface area of $\sim 5 \mathrm{~km}^{2}$ (Jiang et al., 2010). Gahai Lake 1 is a saline lake with a surface area of $\sim 47.2 \mathrm{~km}^{2}$ (Jiang et al., 2010). Tuosu Lake is located on the northeastern corner of the Qaidam Basin. It has an area of $165.9 \mathrm{~km}^{2}$ and the local average annual temperature is $2-4^{\circ} \mathrm{C}$ (Wang and Dou, 1998). Gahai Lake 2 is located on the northeastern edge of the Qaidam Basin. It has a surface area of $32 \mathrm{~km}^{2}$ with the maximum water depth of $13 \mathrm{~m}$. The lake is situated in an arid climate system $(100 \mathrm{~mm}$ of rainfall per year; Wang and Dou, 1998). Xiaochaidan Lake is a hypersaline lake located on the northern edge of the Qaidam Basin. It

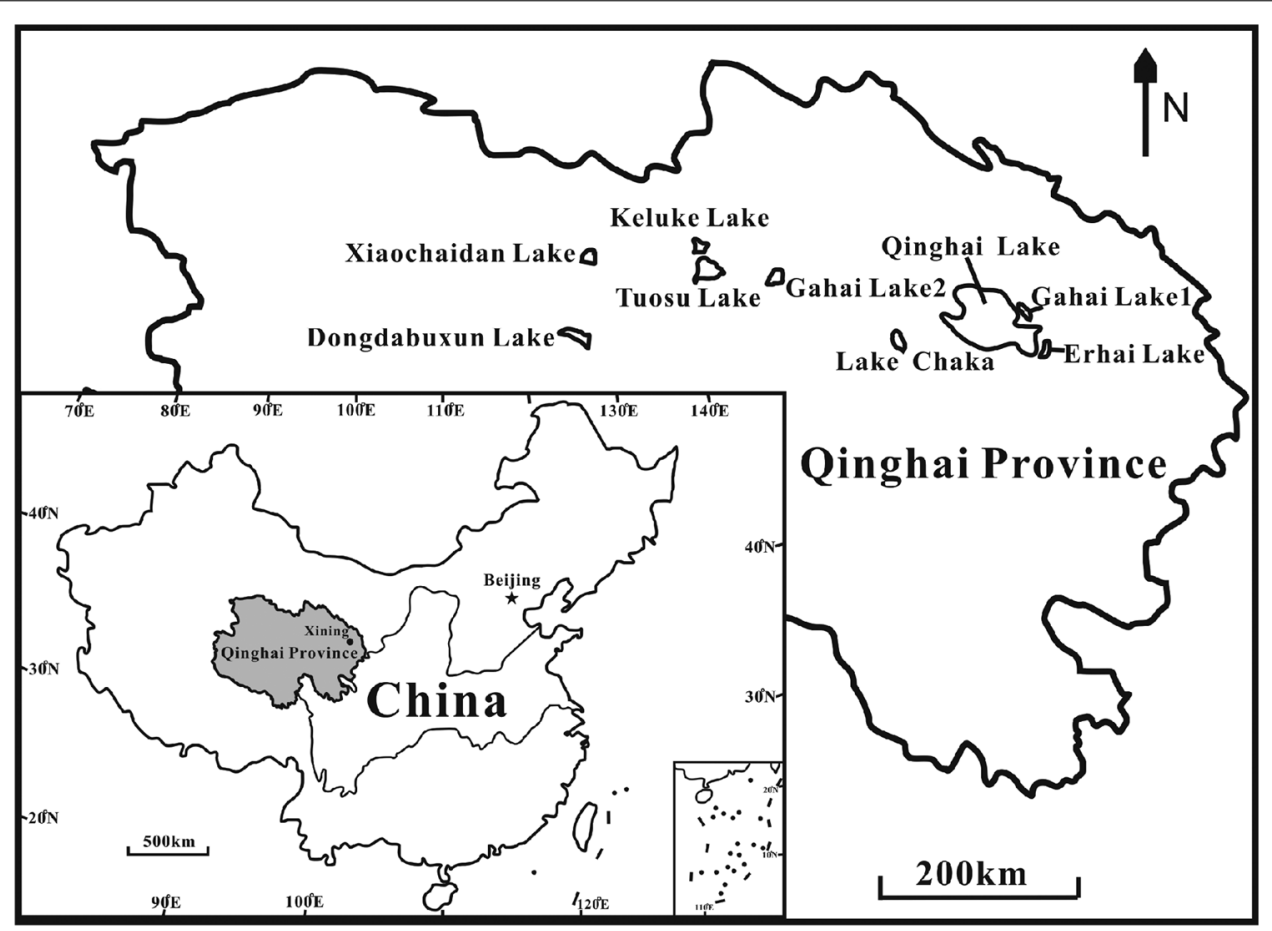

FIGURE 1 | A geographic map showing the locations of the studied lakes on the Qinghai-Tibet Plateau, China. 
has a surface area of $71.5 \mathrm{~km}^{2}$ with the maximum water depth of $0.69 \mathrm{~m}$ (Jiang et al., 2009a). Dongdabuxun Lake is a hypersaline lake located in an extremely arid climate region (average rainfall: $24.7 \mathrm{~mm}$ per year; Wang and Dou, 1998). It has a surface area of 184.0-1001.0 $\mathrm{km}^{2}$ with water depth of $0.36-1.02 \mathrm{~m}$. Lake Chaka is a shallow lake with a high salinity of $32.5 \%$. It has a surface area of $\sim 104 \mathrm{~km}^{2}$ with average water depth of $2-3 \mathrm{~cm}$ (Jiang et al., 2006).

\section{FIELD MEASUREMENTS AND SAMPLE COLLECTION}

Field work was conducted in August 2011. The pH values of the nine lakes were measured with a portable $\mathrm{pH}$ meter (PT-10, Sartorius, Germany). Water chemistry (e.g., sulfide, ammonium, and nitrate) was measured with a Hach colorimeter (model CEL 850, Hach Chemical Co., IA, USA). After field measurements, lake surface water samples $(250-500 \mathrm{~mL})$ were filtered through $0.2 \mu \mathrm{m}$ isopore filters (Whatman, UK). The filtrate $(\sim 40 \mathrm{~mL})$ was collected into $50-\mathrm{mL}$ falcon tubes for aqueous geochemical analysis. For collection of suspended particulate matter (SPM), lake surface waters $(4-20 \mathrm{~L})$ were filtered through $0.7 \mu \mathrm{m}$ pre-combusted Whatman GF/F glass fiber filters. The biomass-containing filters (both 0.2 and $0.7 \mu \mathrm{m}$ ) were subsequently stored on dry ice. Lake sediments at the water-sediment interface were collected into centrifuge tubes (1.5-mL Eppendorf and 50-mL Falcon tubes for DNA and GDGT samples, respectively) and were immediately frozen on dry ice. For the RNA samples, the sediments were mixed with RNAlater (Ambion, USA) with a water: RNAlater ratio of 1:1 (v:v). All water and sediment samples for DNA/RNA extraction and GDGT analysis were transported to the laboratory on dry ice and stored at -80 and $-20^{\circ} \mathrm{C}$, respectively until further analyses.

For clarity, these lake names are hereafter abbreviated as follows: KLKL-1-W, EHL-1-W, QHL-14-W, TSL-31-W, GHL1-32-W, GHL2-84-W, XCDL-160W, DDBXL-308-W, and LCK-325-W for Keluke Lake, Erhai Lake, Qinghai Lake, Tuosu Lake, Gahai Lake 1, Gahai Lake 2, Xiaochaidan Lake, Dongdabuxun Lake, and Lake Chaka, respectively. The numbers between "lake name" and "W" indicates salinity $\left(\mathrm{g} \mathrm{L}^{-1}\right)$ of the lake. KLKL-1-S, EHL-1S, QHL-14-S, TSL-31-S, GHL1-32-S, GHL2-84-S, XCDL-160-S, DDBXL-308-S, and LCK-325-S are used for the sediments of these lakes.

\section{MEASUREMENTS OF WATER SALINITY}

The concentrations of eight major ions: potassium, sodium, calcium, magnesium, chloride, sulfate, carbonate, and bicarbonate were analyzed in the laboratory according to the Manual of Analytical and Testing Department in the Institute of Salt Lakes, Chinese Academy of Science (Analytical Lab of the Qinghai Institute of Salt Lakes, Chinese Academy of Sciences, 1988). Salinity was calculated by summing the concentrations of these eight ions.

\section{THAUMARCHAEOL ANALYSIS}

GF/F filters and sediments ( $\sim 5$ g per sample) were freeze-dried and extracted according to the procedures described previously (Wang et al., 2013). Briefly, samples were ultrasonically extracted three times using a single phase solvent mixture including $\mathrm{MeOH}$, dichloromethane (DCM), and phosphate buffer ( $\mathrm{pH} 7.4 ; 2: 1: 0.8$, $\mathrm{v} / \mathrm{v} / \mathrm{v}$ ) following a previous procedure (Bligh and Dyer, 1959).
Samples were centrifuged ( $5 \mathrm{~min}, 2500 \mathrm{rpm}$ ) and the extract was collected into another tube. This procedure was repeated three times. DCM and phosphate buffer were added to the combined extract at 1:1:0.9 (v/v/v) to achieve phase separation, after which the bottom DCM phase (containing lipids) was collected into a $40 \mathrm{~mL}$ glass tube. The resulting aqueous phase was rinsed twice with DCM and all DCM fractions were collected into a glass tube. Subsequently, the DCM phase containing the total Bligh-Dyer extract (BDE) was dried under $\mathrm{N}_{2}$. To quantify thaumarchaeol a known amount of a $\mathrm{C}_{46}$ internal standard (Huguet et al., 2006) was added to the BDE which was then dissolved in DCM. The resulting mixture was divided into two aliquots: one was dried under $\mathrm{N}_{2}$, re-dissolved in hexane/isopropanol (99:1 v/v), and filtered through a $0.45 \mu \mathrm{m}$ polytetrafluoroethylene (PTFE) filter for analysis of archaeal core lipids (CLs); and the other was subject to acid hydrolysis, and the extracted organic phase was re-dissolved in hexane/isopropanol (99:1, v/v) and filtered through a $0.45 \mu \mathrm{m}$ PTFE filter for archaeal total lipid analysis. The difference in yield of archaeal lipids between the hydrolyzed and non-hydrolyzed fractions is considered to be the archaeal polar lipids (PLs; Zhang et al., 2011). The thaumarchaeol was determined by using high performance liquid chromatography (HPLC)-atmospheric pressure chemical ionization (APCI)-mass spectrometry (MS) at Tongji University following a method slightly modified from previous studies (Hopmans et al., 2004; Schouten et al., 2007). An aliquot $(5 \mu \mathrm{l})$ of sample was injected and separation was achieved with an Alltech Prevail Cyano Column (150 mm $\times 2.1 \mathrm{~mm}, 3 \mu \mathrm{m})$. The elution gradient was: isocratic (5 $\mathrm{min}$ ) at $99 \%$ hexane/1\% isopropanol followed by a linear gradient to $1.8 \%$ propanol in $45 \mathrm{~min}$ at a constant flow rate of $0.2 \mathrm{ml} \mathrm{min}^{-1}$. Quantification was achieved by peak area integration of $[\mathrm{M}+1]^{+}$ions in the extracted ion chromatogram in comparison with the $\mathrm{C}_{46}$ internal standard. The detection limit was $0.8 \mathrm{pg}$ (Zhang et al., 2011).

\section{NUCLEIC ACIDS EXTRACTION}

DNA was extracted from biomass-containing filters and lake sediments by using FastDNA Pro soil-direct kits (MP Biomedicals, $\mathrm{OH}$, USA) according to the manufacturer's instructions. The amoA transcripts have been recovered from Qinghai Lake (Jiang et al., 2009b) and oceans (with salinity higher than Gahai Lake 1; Pitcher et al., 2011b). In order to test whether the amoA gene transcripts can be recovered from saline lakes (with salinity higher that of seawater), sediment samples from Gahai Lake 2 and Xiaochaidan Lake were selected for RNA extraction using FastRNA Pro soil-direct kits (MP Biomedicals) according to the manufacturer's protocol. DNA-based amoA gene PCR was not successful in Lake Chaka, so RNA was not extracted from the sediment of Lake Chaka). The extracted raw RNA was digested with the use of RNase-free DNase I (Takara, Japan). The DNase-digested RNA samples were checked for potential geonomic DNA contamination by PCR amplification with the AOA-specific primer set (see "PCR Amplification and Phylogenetic Analysis"). The checked RNA samples were reverse-transcribed into cDNA using the Promega AMV reverse transcription system (Promega Corporation, Madison, WI, USA) as previously described (Yang et al., 2012). Double distilled water served as the template in negative controls for the cDNA synthesis and downstream PCRs (Jiang et al., 2010). 


\section{QUANTITATIVE PCR}

Quantitative PCR ( $\mathrm{PPCR}$ ) was used to determine the abundances of the archaeal 16S rRNA and amoA genes in the waters and sediments of the nine lakes with the primer sets of Arch349F (5'-GYG CAS CAG KCG MGA AW-3')/Arch806R (5'-GGA CTA CVS GGG TAT CTA AT-3'; Takai and Horikoshi, 2000), and ArchamoAF (5' -STAATGGTCTGGCTTAGACG-3')/Arch-amoAR (5' GCGGCCATCCATCTGTATGT-3'; Francis et al., 2005), respectively. qPCRs were performed in a reaction volume of $20 \mu \mathrm{L}$, containing $10 \mu \mathrm{L}$ of $2 \times$ SYBR $^{\circledR}$ Premix Ex Taq ${ }^{\mathrm{TM}}$ (Takara), $0.4 \mu \mathrm{M}$ of each primer, $0.4 \mu \mathrm{L}$ of ROX reference dye II $(50 \times)$, and $1 \mu \mathrm{L}$ of soil DNA. qPCRs were performed on an ABI7500 real-time PCR system (Applied Biosystems, Carlsbad, CA, USA). The qPCRs were performed with the following conditions: $95^{\circ} \mathrm{C}$ for $30 \mathrm{~s}$, followed by 40 cycles $\left(5 \mathrm{~s}\right.$ at $95^{\circ} \mathrm{C}$ for denaturing, $34 \mathrm{~s}$ for annealing at $53^{\circ} \mathrm{C}$ for the archaeal $16 \mathrm{~S}$ rRNA and $a m o A$ genes, and $60 \mathrm{~s}$ at $72^{\circ} \mathrm{C}$ ). A dissociation stage was added to yield a dissociation curve after the cycling amplification step. Standard curves were obtained by using serial dilutions $\left(10^{1}\right.$ to $10^{7}$ copies $)$ of plasmids (pGEM-T) containing cloned archaeal $16 \mathrm{~S}$ rRNA and amoA genes. The data were used to create standard curves correlating the $C_{\mathrm{t}}$ values with the archaeal $16 \mathrm{~S}$ rRNA and amoA gene copy numbers. Linear plots (not shown) between the $C_{t}$ value and $\log$ (copy numbers/reaction) were obtained with correlation coefficients of $R^{2}>0.99$. PCR efficiencies were 90-95\%. The quality and length of the qPCR products were checked by dissociation curve analysis and 1\% agarose gel electrophoresis. The qPCR results were expressed as gene copies per gram (copies $\mathrm{g}^{-1}$ ) for sediments and gene copies per milliliter (copies $\mathrm{mL}^{-1}$ ) for water samples.

\section{PCR AMPLIFICATION AND PHYLOGENETIC ANALYSIS}

Five lakes (Erhai Lake, Gahai Lake 1, Gahai Lake 2, Xiaochaidan Lake, and Lake Chaka) were selected for the AEA amoA gene diversity analysis. Two primer sets of ArchamoAF/Arch-amoAR (Francis et al., 2005) and CrenamoA23f (5'-ATGGTCTGGCTWAGACG-3')/CrenamoA616r (5'-GCCATC CATCTGTATGTCCA-3'; Tourna et al., 2008) were used to PCRamplify the archaeal amoA genes from the extracted DNA and synthesized cDNA. Each PCR mixture $(25 \mu \mathrm{L}$ reaction volume) contained the following ingredients: $2.5 \mu \mathrm{L} 10 \times$ buffer (Takara), $2 \mu \mathrm{L}$ deoxynucleoside triphosphate (dNTP; a $2.5 \mathrm{mM}$ dNTP; Takara), 16.2 $\mu \mathrm{L}$ sterilized ultra pure water (Millipore), $1 \mu \mathrm{L}$ bovine serum albumin (BSA; Takara), $1 \mu \mathrm{L}$ each primer (10 pmole), and $0.3 \mu \mathrm{L}$ rTaq DNA polymerase (Takara). PCR conditions were same as those described previously (Francis et al., 2005; Tourna et al., 2008). The resulting PCR products (635 and $629 \mathrm{bp}$ from the primer sets of Arch-amoAF/Arch-amoAR and CrenamoA23f/CrenamoA616r, respectively) were examined on $1 \%$ agarose gel and no bands were observed for PCR negative controls (with distilled water as the template). PCRs failed for the DNA samples from Lake Chaka (with $325 \mathrm{~g} \mathrm{~L}^{-1}$ salinity). Transcription of archaeal amoA gene was shown to occur in Erhai Lake and Gahai Lake 1 in our previous study (Jiang et al., 2009b). Therefore cDNA synthesis was performed only on the samples from Gahai Lake 2 and Xiaochaidan Lake. However, Xiaochaidan Lake cDNA sample was only successfully amplified with primer Arch-amoAF/Arch-amoAR. The appropriate bands were excised and PCR gels were purified with Agarose Gel DNA purification Kit (Takara). The purified PCR products were ligated into the pGEM$\mathrm{T}$ vector (Promega Inc.) and transformed into Escherichia coli JM109 competent cells (Takara) according to the manufacturer's instructions. The transformed cells were spread on Luria-Bertani plates containing $100 \mu \mathrm{g} \mathrm{mL}^{-1}$ of ampicillinsodium, $80 \mu \mathrm{g} \mathrm{mL}^{-1}$ of X-Gal (5-bromo-4-chloro-3-indolyl- $\beta$-D-galactopyrano-side), and $0.5 \mathrm{mM}$ IPTG (isopropyl- $\beta$-D-thiogalactopyranoside) and cultivated overnight at $37^{\circ} \mathrm{C}$.

Sixteen (eight for each primer set) DNA clone libraries were constructed from the following samples: EHL-1-W, GHL1-32-W, GHL2-84-W, XCDL-160-W, EHL-1-S, GHL1-32-S, GHL2-84-S, and XCDL-160-S. One cDNA clone library (XCDL-160-SR) was constructed for the sediment from Xiaochaidan Lake. Around 30-40 randomly selected clones per sample were analyzed for the insert amoA gene sequences. Positive clones were sequenced using M13F with the BigDye Terminator version 3.1 chemistry (Applied Biosystems, Foster City, CA, USA) on an ABI 3730 automated sequencer.

The obtained raw nucleotide sequences were checked and trimmed manually by using the BioEdit program ${ }^{1}$. The sequences of poor quality were removed from further analysis. The operational taxonomic units (OTUs) of the amoA gene clone sequences were determined based on a cutoff value of $98 \%$ by using nearest neighbor algorithm in the DOTUR program (Schloss and Handelsman, 2005). The saturation of the sampled clones from each amoA gene clone library was assessed by calculating the coverage $(C)$ values as follows: $C=1-(n 1 / N)$, where $n 1$ is the number of OTUs that occurred only once in the clone library and $N$ is the total number of analyzed clones (Jiang et al., 2006). One representative sequence was selected from each OTU for phylogenetic analysis. Closest references of the amoA gene were retrieved from the GenBank ${ }^{2}$ using BLAST. Maximum likelihood trees were constructed from the amoA gene sequences obtained in this study and their references (Pester et al., 2012) with the use of the MEGA program version 5.0 (Tamura et al., 2011), and were assessed using 1000 bootstrap replications. The nucleotide sequences obtained in this study were deposited in the GenBank database under accession numbers JX488399-JX488453 and KF606897-KF606927.

\section{STATISTICAL ANALYSIS}

Diversity indices were calculated by using DOTUR. LIBSHUFF analysis was performed to discern any similarity of the amoA gene composition among the samples according to the methods described previously (Jiang et al., 2006). Mantel test was performed to assess the correlations between amoA gene populations and environmental factors according to the procedures described previously (Yang et al., 2013). Briefly, the biotic matrices of amoA gene composition were constructed with the Bray-Curtis distance defined as follows: Bray-Curtis distance $=1-d$, where $d$ refers to the Bray-Curtis similarity index, and the abiotic matrices of environmental variables were constructed using the Euclidean distance.

\footnotetext{
${ }^{1}$ http://www.mbio.ncsu.edu/bioedit/bioedit.html

${ }^{2}$ http://www.ncbi.nlm.nih.gov
} 
Cluster analysis was performed to compare differences in AEA communities between the studied Tibetan lakes and other lakes and saline environments worldwide (Francis et al., 2005; Dang et al., 2009; Herrmann et al., 2009; Jiang et al., 2009b; Kalanetra et al., 2009; Pouliot et al., 2009; Llirós et al., 2010; Wu et al., 2010; Auguet et al., 2011; Table 1). In order to avoid any bias resulting from different primers, those archaeal amoA gene sequences derived from the same primer set, Arch-amoAF/Arch-amoAR (Francis etal., 2005) were included in the cluster analysis. The combined amoA gene sequences $(\sim 635 \mathrm{bp})$ were subjected to OTU identification using the DOTUR program (Schloss and Handelsman, 2005). The Jaccard similarity matrices were made and topology trees were constructed using the PAST software package ${ }^{3}$.

\section{RESULTS}

\section{WATER CHEMISTRY OF THE STUDIED LAKES}

The salinities of the investigated lakes were $0.7,1.0,14.2,31.3$, 31.9, 84.0, 160.4, 307.6, $325.0 \mathrm{~g} \mathrm{~L}^{-1}$ for Keluke Lake, Erhai Lake, Qinghai Lake, Tuosu Lake, Gahai Lake 1, Gahai Lake 2,

${ }^{3}$ http://folk.uio.no/ohammer/past/
Xiaochaidan Lake, Dongdabuxun Lake, and Lake Chaka, respectively (Table 2). The $\mathrm{pH}$ was 7.0-9.4. The concentrations of sulfide ranged from 0.0 to $0.2\left(\mathrm{mg} \mathrm{L}^{-1}\right.$; Table 2$)$. The concentrations of major cations and anions of the investigated lake waters ranged as follows $\left(\mathrm{mg} \mathrm{L}^{-1}\right): \mathrm{K}^{+}(6.5-2163.0), \mathrm{Na}^{+}$(135.2-107460.3), $\mathrm{Ca}^{2+}$ (17.7-1711.0), $\mathrm{Mg}^{2+}(53.6-24700.0), \mathrm{SO}_{4}^{2-}(117.9-17099.8), \mathrm{Cl}^{-}$ (206.2-196231.9), $\mathrm{CO}_{3}^{2-}(0.0-515.4), \mathrm{HCO}_{3}^{2-}(149.8-824.1)$ $\mathrm{NH}_{4}^{+}(0.4-1.2)$, and $\mathrm{NO}_{3}^{-}(0.2-1.4$; Table 2$)$.

\section{ABUNDANCE OF THAUMARCHAEOL}

In the lake waters, thaumarchaeol concentration ranged from 0.0 to $0.3 \mathrm{ng} \mathrm{L} \mathrm{L}^{-1}$ for CLs and from 0.0 to $0.5 \mathrm{ng} \mathrm{L^{-1 }}$ for PLs; in the lake sediments, thaumarchaeol concentrations ranged from 0.1 to $25.2 \mathrm{ng} \mathrm{g}^{-1}$ for CLs and 0.5 to $37.5 \mathrm{ng} \mathrm{g}^{-1}$ for PLs (Figure 2). The highest thaumarchaeol concentrations were observed in the sediment of Tuosu Lake (salinity: $31 \mathrm{~g} \mathrm{~L}^{-1}$ ): 25.2 and $37.5 \mathrm{ng} \mathrm{g}^{-1}$ for CLs and PLs, respectively (Figure 2).

ABUNDANCE OF ARCHAEAL 16S rRNA AND amoA GENES

Total archaeal 16S rRNA gene abundance ranged from $3.86 \times 10^{4}$ to $4.15 \times 10^{6}$ copies $\mathrm{mL}^{-1}$ and from $1.66 \times 10^{5}$ to

Table 1 | Summary of the AEA amoA gene sequences used for the comparison between this and other studies (the AEA amoA gene sequences were derived from the primer set of Francis et al. (2005), and the length of the amoA gene sequences was $635 \mathrm{bp}$.

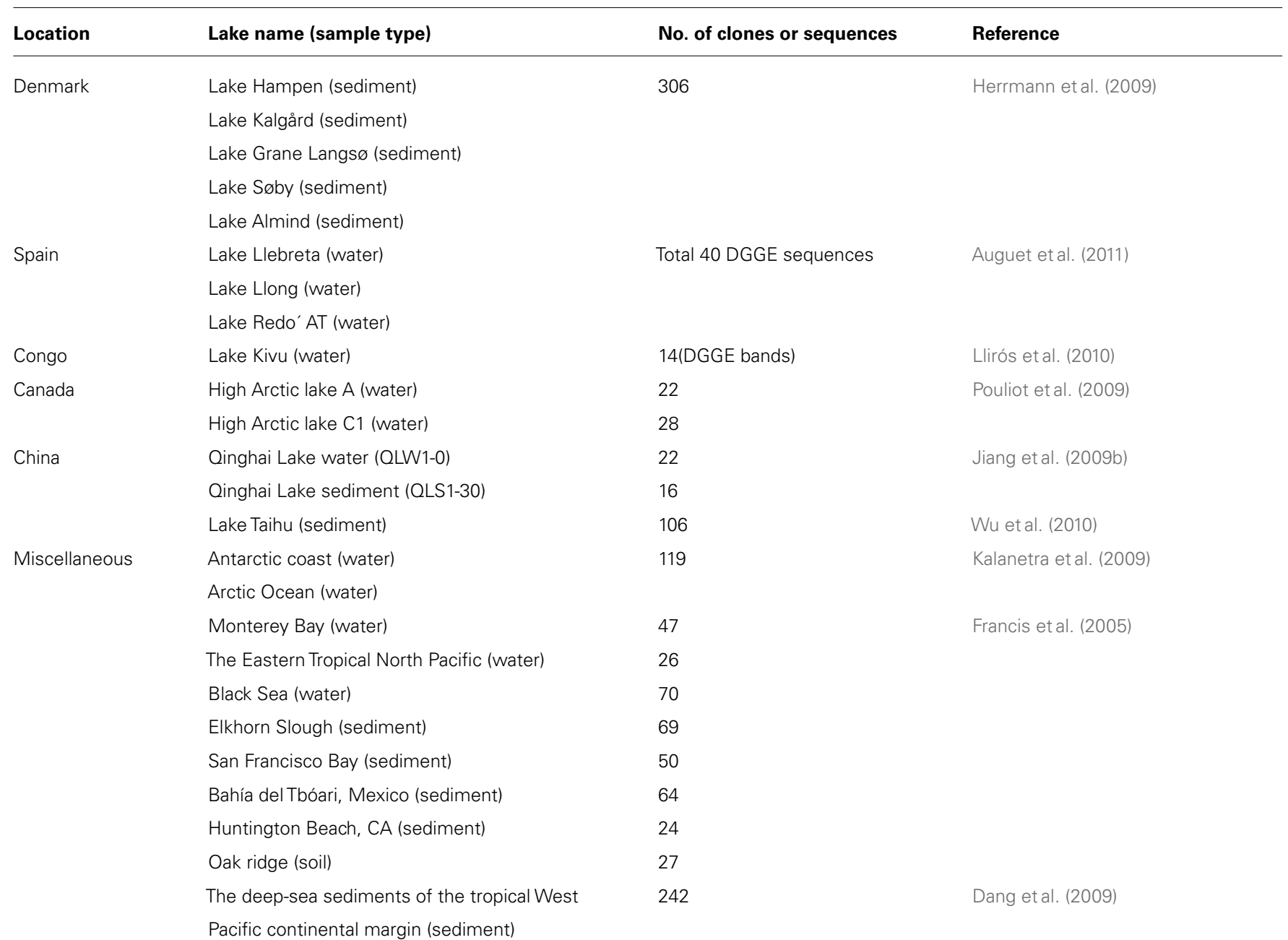




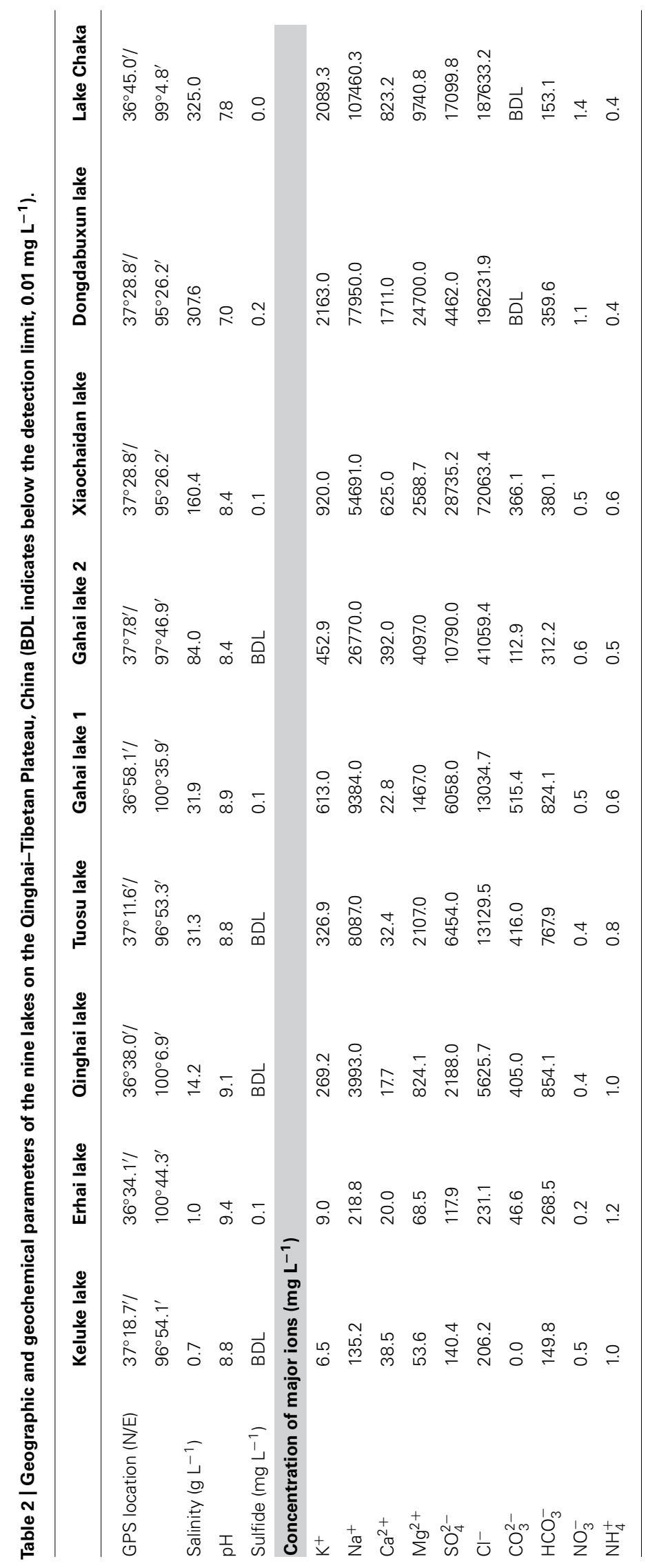




\section{A Water samples}

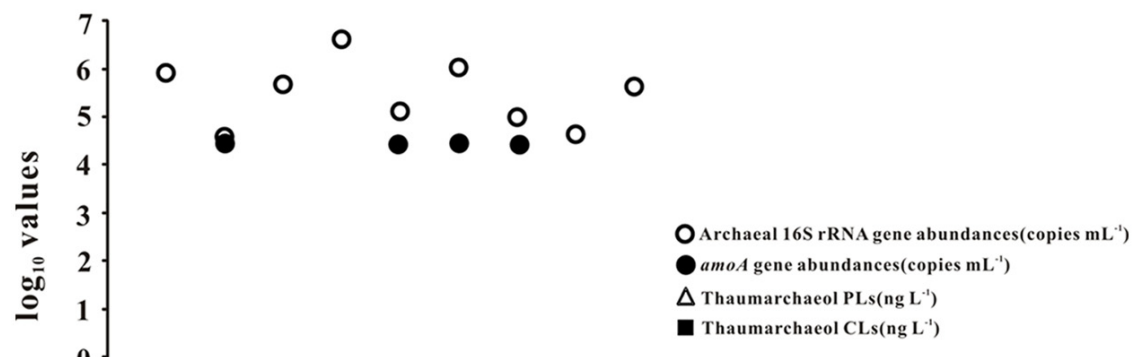

B Sediment samples

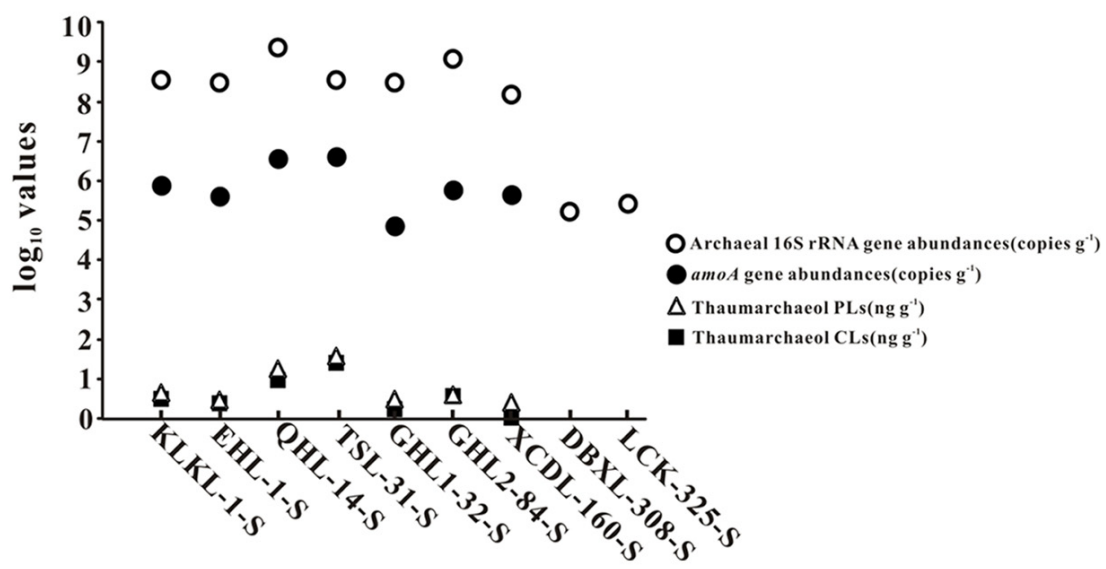

FIGURE 2 |The abundances (copies per gram of sediment or copies per milliliter of water) of total archaeal 16S rRNA and amoA genes and thaumarchaeol concentrations (nanogram per liter of water and nanogram per gram of sediment). Panels (A) and (B) are for waters and sediments, respectively.

$2.33 \times 10^{9}$ copies $\mathrm{g}^{-1}$ for the waters and sediments, respectively (Figure 2). The amoA gene abundance ranged from $2.81 \times 10^{4}$ $3.07 \times 10^{4}$ copies $\mathrm{mL}^{-1}$ and $7.34 \times 10^{4}-4.13 \times 10^{6}$ copies $^{-1}$ for the waters and sediments, respectively (Figure 2). The highest water and sediment $16 \mathrm{~S}$ rRNA archaeal abundances were observed in the water of Tuosu Lake $\left(4.15 \times 10^{6}\right.$ copies $\left.\mathrm{mL}^{-1}\right)$ and the sediment of Qinghai Lake $\left(2.33 \times 10^{9}\right.$ copies $\left.\mathrm{g}^{-1}\right)$; whereas the highest water and sediment archaeal amoA gene abundances were observed in the water of Gahai Lake $1\left(3.07 \times 10^{4}\right.$ copies $\left.\mathrm{mL}^{-1}\right)$ and the sediment of Tuosu Lake $\left(4.13 \times 10^{6}\right.$ copies $\left.\mathrm{g}^{-1}\right)$. In addition, the amoA gene abundance exhibited a significant correlation (CL: $r=0.879, P=0.009$; PL: $r=0.928, P=0.003$ ) with thaumarchaeol abundance for the sediment samples (except Lake Chaka, where no amoA gene abundance data were available; Figure 3 ).

\section{amoA GENE PHYLOGENETIC ANALYSIS}

A total of 283 (187 and 96 from the two primer sets of ArchamoAF/Arch-amoAR and CrenamoA23f/CrenamoA616r, respectively) amoA gene clone sequences were obtained (Table 3 ).

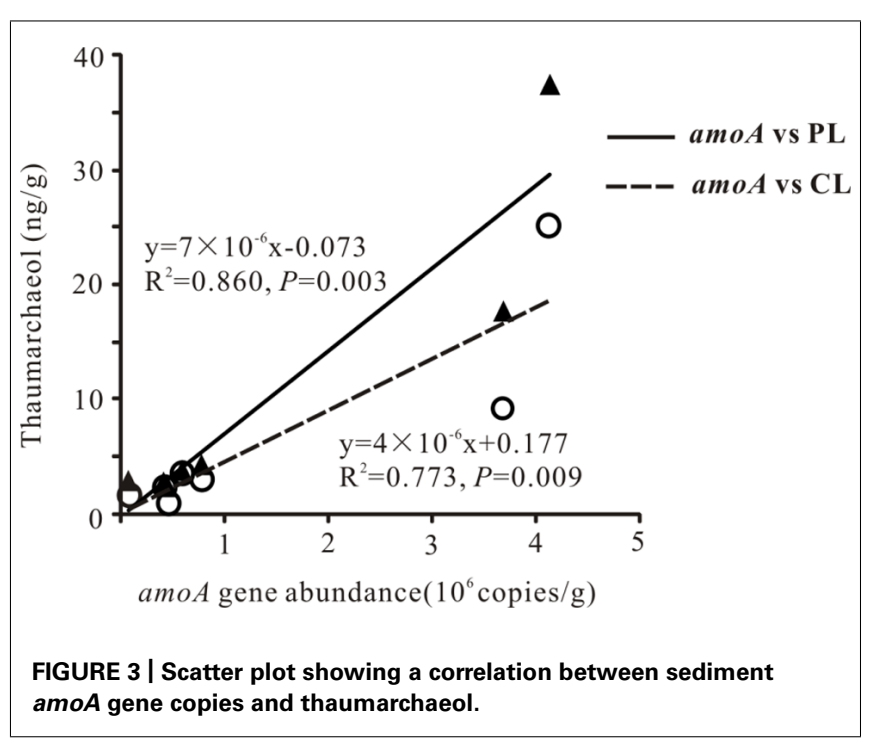




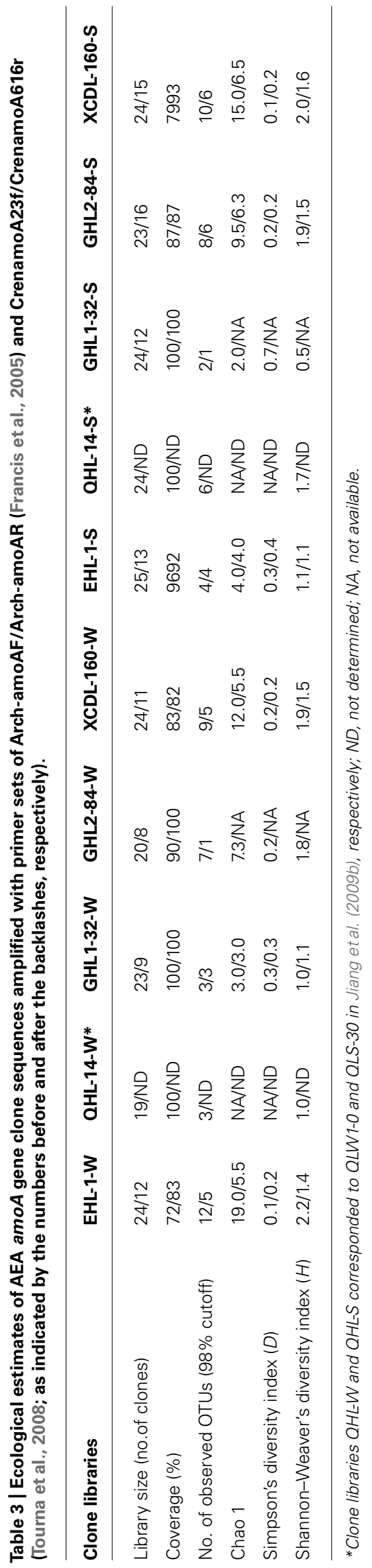


A

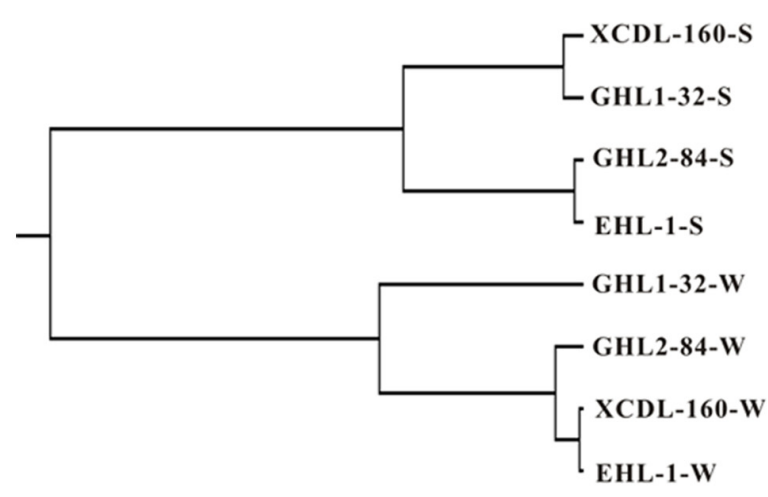

B

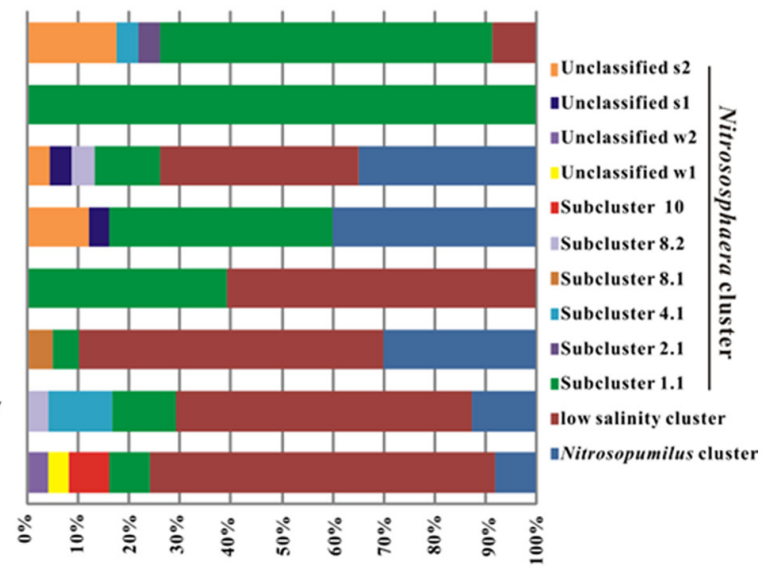

FIGURE 4 | (A) Clustering of the different amoA gene clone libraries based on $\triangle \mathrm{Cxy}$ values determined from the LIBSHUFF analysis. The tree was constructed with the unweighted-pair group method using average linkages in MEGA 5. The parameter $\triangle \mathrm{Cxy}$ in the LIBSHUFF analysis represents the difference in coverage of any two clone libraries (the larger $\Delta \mathrm{Cxy}$, the greater dissimilarity between the given clone libraries). The software for the analysis was available at http://whitman.myweb.uga.edu/libshuff.html.

(B) Schematic figure showing the frequencies of OTUs (at $98 \%$ nucleotide cutoff) affiliated with major phylogenetic groups in the amoA gene clone libraries.
The amoA gene clone sequences derived from the primer set of Arch-amoAF/Arch-amoAR were clustered into 55 OTUs: 12, 3, 7 , and 9 for the water samples and 4, 2, 8, and 10 for the sediment samples of Erhai Lake, Gahai Lake 1, Gahai Lake 2, and Xiaochaidan Lake, respectively (Table 3 ). The coverage ranged from 72 to $100 \%$ for the amoA gene clone libraries (Table 3 ). Diversity indices were 2.0-19.0, 0.1-0.7, and 0.5-2.2 for Chao1, Simpson, and Shannon-Weaver, respectively (Table 3 ).

In comparison, the amoA gene diversity derived from CrenamoA23f/CrenamoA616r was lower than that from the Arch-amoAF/Arch-amoAR primer set. These amoA gene clone sequences fell into 31 OTUs: $5,3,1$, and 5 for the water samples, and 4, 1, 6, and 6 for the sediment samples of Erhai Lake, Gahai Lake 1, Gahai Lake 2, and Xiaochaidan Lake, respectively (Table 3 ). The coverage ranged from 82 to $100 \%$ for the amoA gene clone libraries (Table 3). Diversity indices were 3.0-6.5, 0.2-0.4, and 1.1-1.6 for Chao1, Simpson, and Shannon-Weaver, respectively (Table 3).

The LIBSHUFF analysis showed that the archaeal amoA gene clone libraries were grouped into two separate clusters (one each for the waters and sediments, respectively; $P$-value $<0.01$; Figure 4A).

The amoA gene clone sequences obtained from the waters were grouped into the Nitrososphaera clusters (subcluster 1.1, 4.1, 8.1, 8.2, 10, and unclassified w1 and w2), Nitrosopumilus clusters and "low salinity" cluster (Mosier and Francis, 2008; Figures $4 \mathbf{B}$ and $\mathbf{5 A}$ ). The "low salinity" cluster was the predominant component (accounting for 62.6\%) in the total water $a m o A$ gene clone sequences. The amo $A$ gene clone sequences in the "low salinity" cluster had high an identity ( 98\%) with the clones from the San Francisco Bay estuary (Francis etal., 2005; Mosier and Francis, 2008) and a low-salinity ammoniaoxidizing archaeon "Candidatus Nitrosoarchaeum limnia"
(Blainey etal., 2011). The amoA gene clone sequences in the Nitrosopumilus cluster were closely related (approximately 98\% identity) to the clones retrieved from diverse environments, such as drinking water treatment plant (van der Wielen et al., 2009), Tibetan marsh wetland (unpublished), freshwater flow channel (Herrmann etal., 2011), waters near the Three Gorges Dam of Yangtze River (Huang et al., 2011), and freshwater sediment enrichment clones (AOA-AC5 and AOA-DW; French etal., 2012b). The amoA gene clone sequences in the Nitrososphaera cluster showed close relatedness ( $~ 98 \%$ identity) to clones from soils (unpublished), estuary sediments (Beman and Francis, 2006), Qinghai Lake sediments (Jiang et al., 2009b), and a AOA isolate Nitrososphaera viennensis EN76 (Tourna et al., 2011).

For the sediment samples, the obtained amoA clone sequences were grouped into the Nitrososphaera clusters (subcluster 1.1, 2.1, 4.1, 8.2, and unclassified s1 and s2), Nitrosopumilus clusters and "low salinity" Cluster (Figures 4B and 5B), with the Nitrososphaera 1.1 cluster being the dominant $(55.2 \%$ of the obtained sediment AOA amoA gene clone sequences). The amoA gene clone sequences in the Nitrososphaera 1.1 cluster were closely related (approximately 98\% identity) to clones retrieved from diverse environments, such as waste water bioreactors (NCBI database), littoral wetland soils (Wang et al., 2012), wetland sediments (Wang et al., 2011), aquaculture farm sediments (Dang et al., 2010), alpine soils (Zhang et al., 2009), sandy soils (Leininger et al., 2006), and Qinghai Lake sediments (Jiang et al., 2009b). The amoA gene clone sequences in the Nitrosopumilus cluster showed a high similarity ( $98 \%$ ) to clones from Lake Taihu sediment (Wu et al., 2010), drinking water treatment plants (van der Wielen et al., 2009), and freshwater sediment enrichment clones (AOA-AC5 and AOA-DW; French et al., 2012b). The amoA gene clone sequences in the "low salinity" cluster had high an identity ( $\sim 98 \%)$ with the clones from 
the San Francisco Bay sediment (Francis et al., 2005; Mosier and Francis, 2008) and drinking water treatment plants (van der Wielen et al., 2009). In addition, the cDNA-based AEA amoA gene clone sequences $(n=12)$ from Xiaochaidan Lake were grouped into one OTU and were affiliated with S_1.1 subcluster within Nitrososphaera (Figure 5B).

\section{STATISTICAL ANALYSIS}

The abundances of amoA gene and thaumarchaeol did not show any significant correlations with any of the measured environmental variables, such as $\mathrm{pH}$, salinity, salinity-related ions, ammonium, nitrate, and sulfide (data not shown). No significant correlation was observed between the amoA gene composition (at the 98\% similarity OTU level) and water chemistry (data not shown). The simple Mantel test showed no significant correlation between AEA composition and salinity at the $98 \%$ similarity OTU level (water samples: $r=-0.491, P=0.872$ or sediment samples: $r=0.587, P=0.132$ ).

Cluster analysis showed that the AEA communities in the lakes (including the saline/hypersaline lakes in this study and the freshwater lakes in other studies) within China were grouped into one cluster, separated from other freshwater lakes (except for the high Arctic Lake C1) around the world (e.g., Canada, Congo, Spain, Denmark; Figure 6). In addition, the AEA communities in Tibetan lakes exhibited little similarity to those in other saline habitats, such as the waters of Monterey Bay, the Eastern Tropical North Pacific, the Black Sea, Arctic Ocean, and Antarctic coasts (Figure 7A) and sediment samples from Elkhorn Slough, and Huntington Beach of California, Bahía del Tbóari of Mexico, San Francisco Bay, and the tropical West Pacific Continental Margin and a Oak Ridge soil (Figure 7B).

\section{DISCUSSION \\ OCCURRENCE OF THAUMARCHAEOL IN HYPERSALINE OINGHAI-TIBETAN LAKES}

Thaumarchaeol was observed from the waters and sediments of Gahai Lake2, Xiaochaidan Lake, and Lake Chaka (salinity: 84, 160, and $325 \mathrm{~g} \mathrm{~L}^{-1}$, respectively). Their salinities were much higher than those in other lakes where thaumarchaeol has been reported (Blaga et al., 2009; Sinninghe Damsté et al., 2009; Bechtel et al., 2010; Tierney et al., 2010; Pearson et al., 2011; Buckles et al., 2013). Many previous studies indicated that thaumarchaeol is a specific membrane lipid biomarker of Thaumarchaeota (Pearson et al., 2004; Zhang et al., 2006; Pester et al., 2011; Pitcher et al., 2011a; Sinninghe Damsté et al., 2012). So far, thaumarchaeol has not been discovered in other archaea suggesting that thaumarchaeol may be used as a characteristic tracer for Thaumarchaeota in the environment. A possible explanation for the occurrence of thaumarchaeol in such high-salinity lakes is that some AOA in Tibetan lakes may have adapted to higher salinity than that of seawater. This possibility was supported by the presence of archaeal amoA gene in these lakes, except for the Lake Chaka $\left(325.0 \mathrm{~g} \mathrm{~L}^{-1}\right)$ where the amoA gene could not be amplified. Indeed, the hypersaline Lake Chaka is optimal for halophilic Euryarchaeota but not for Crenarchaeota/Thaumarchaeota (Jiang et al., 2006, 2007; Auguet et al., 2009). However, we observed higher PL thaumarchaeol concentration in the Lake Chaka sediment than in other hypersaline lakes. The inconsistency between amoA gene result and thaumarchaeota data in Lake Chaka could be ascribed to the following possible reasons: (1) different detection limits between these two methods (qPCR vs. lipid biomarker); (2) preferential degradation of DNA/RNA relative to lipid (Castañeda and Schouten, 2011; Schouten et al., 2013). PL GDGTs may contain a number of GDGTs that have sugar or phosphate groups, and a majority of the PLs (especially glycolipids) in environmental samples might be a result of the selective preservation of fossil lipids (Schouten et al., 2010); (3) the PCR primers used in this study may be limited to amplify all AEA amo $A$ genes. For example, the amo $A$ genes from genus Nitrosocaldus cannot be detected with the primers used in this study (de la Torre et al., 2008); (4) additional sources of thaumarchaeota other than AEA; (5) Transport of thaumarchaeota from surrounding soils by rain runoff and dust particles by wind, where amoA gene may have been preferentially degraded. Lake Chaka is a small and shallow lake that is surrounded by soil. When PL GDGTs from surrounding soil was washed into the lake, it can quickly deposit into sediment. GDGTs are difficult to degrade even under oxic conditions (Kim et al., 2009) and thus they can be preserved in sediments for million years (Schouten et al., 2013). However, further investigation is required for the exact reasons for the presence of high GDGT in the Qinghai-Tibetan hypersaline lakes.

\section{AEA COMMUNITY COMPOSITION IN OINGHAI-TIBETAN LAKES AND THEIR RESPONSE TO ENVIRONMENTAL CHANGES}

In recent years, there have been numerous studies to reveal AEA diversity and community composition in freshwater lakes and their relationships with environmental conditions (Herrmann et al., 2009; Pouliot et al., 2009; Llirós et al., 2010; Wu et al., 2010; Auguet et al., 2011, 2012; French et al., 2012a; Auguet and Casamayor, 2013; Hugoni et al., 2013; Vissers et al., 2013). However, systematic AOA studies in saline/hypersaline lakes are still sparse, except for Qinghai Lake and some high-altitude lakes (Jiang et al., 2009b; $\mathrm{Hu}$ et al., 2010), likely due to the fact that no AOA cultures have ever been obtained from (hyper)saline environments with salinity higher than that of seawater. Life in hypersaline environments is energetically expensive because microorganisms need to cope with osmotic stress (Oren, 2011). Although ammonia oxidation is an energy-yielding process (Könneke et al., 2005), the known AOA are often limited to those environments with salinities less than that of seawater, because of this energetic consideration. Thus, it is not surprising to retrieve archaeal amoA genes from Erhai and Gahai Lake 1 because of their low salinities (< seawater salinity). However, it was unexpected to retrieve archaeal amo $A$ genes from hypersaline Gahai Lake2 and Xiaochaidan Lake. Interestingly, cDNA-based archaeal amoA gene PCR was successful for the sediments of Xiaochaidan Lake and the resulting amoA gene sequences were different from DNA-based sequences. This suggested that AEA might be active in hypersaline lakes with a salinity up to $160 \mathrm{~g} \mathrm{~L}^{-1}$. In addition, the majority of the AEA amoA gene clone sequences obtained from these lake water samples were affiliated with the "low salinity" cluster, and were widely distributed in different lakes, suggesting that some low-salinity AEA may have adapted to a wide salinity range in Qinghai-Tibetan lakes. In addition, the amino acid sequences from the amo $A$ gene clones of this 

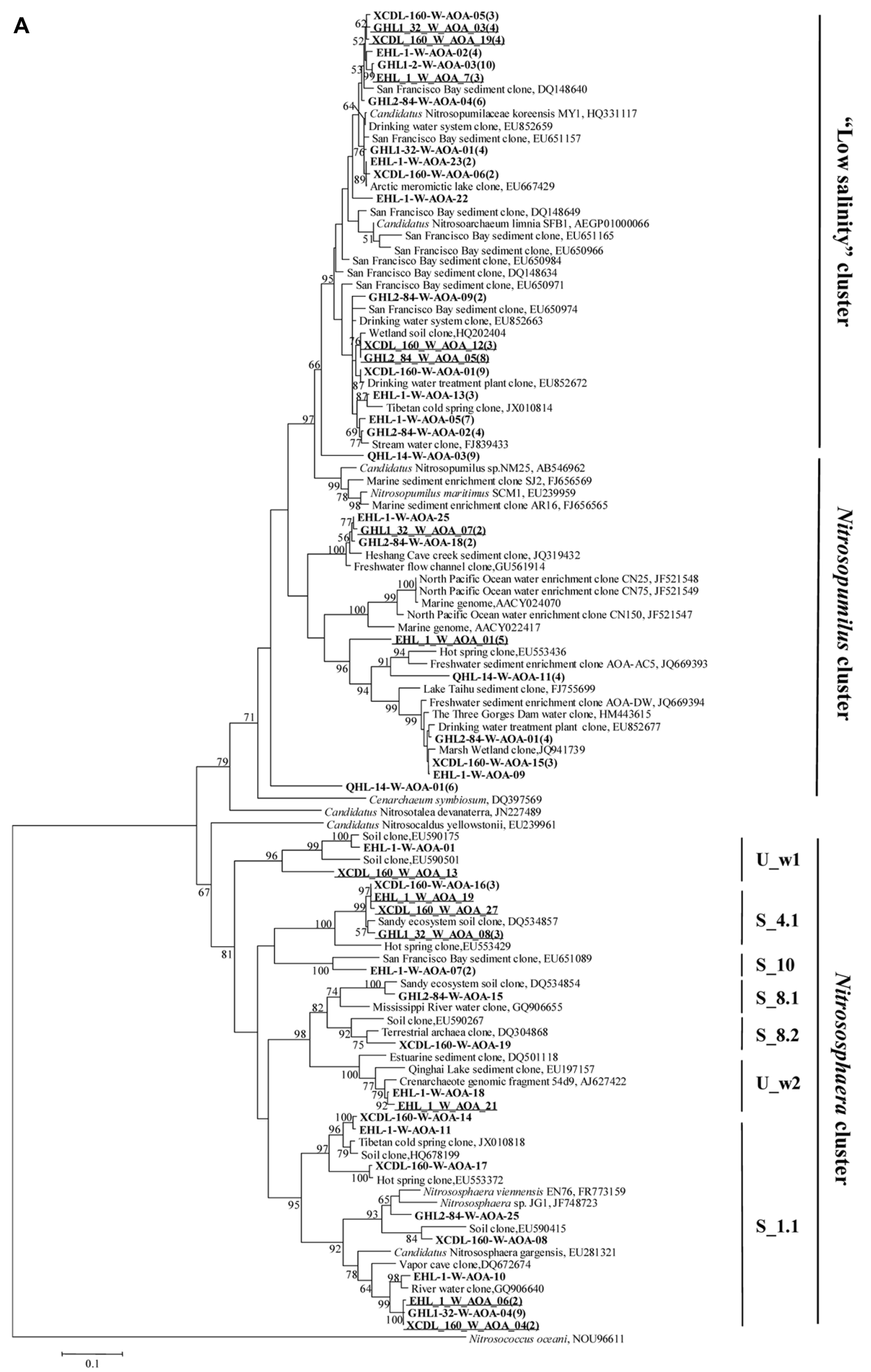

FIGURE 5 | Maximum likelihood tree (partial sequences, 635 or 629 bp) showing the phylogenetic relationships of the amoA gene clone sequences obtained in this study to their closely related sequences from the GenBank database. One representative clone type within each OTU is shown, and the number of clones within each OTU is shown in parentheses.
If there is only one clone sequence within a given OTU, the number " 1 " is omitted. The sequences from this study are bolded, and they are coded as follows for the example of XCDL-S-AOA-17: amoA sequences of clone no. 17 from the Xiaochaidan Lake sediment. Clone libraries $\mathrm{QHL}-14-\mathrm{W}$ and $\mathrm{QHL}-14-\mathrm{S}$ (Continued) 


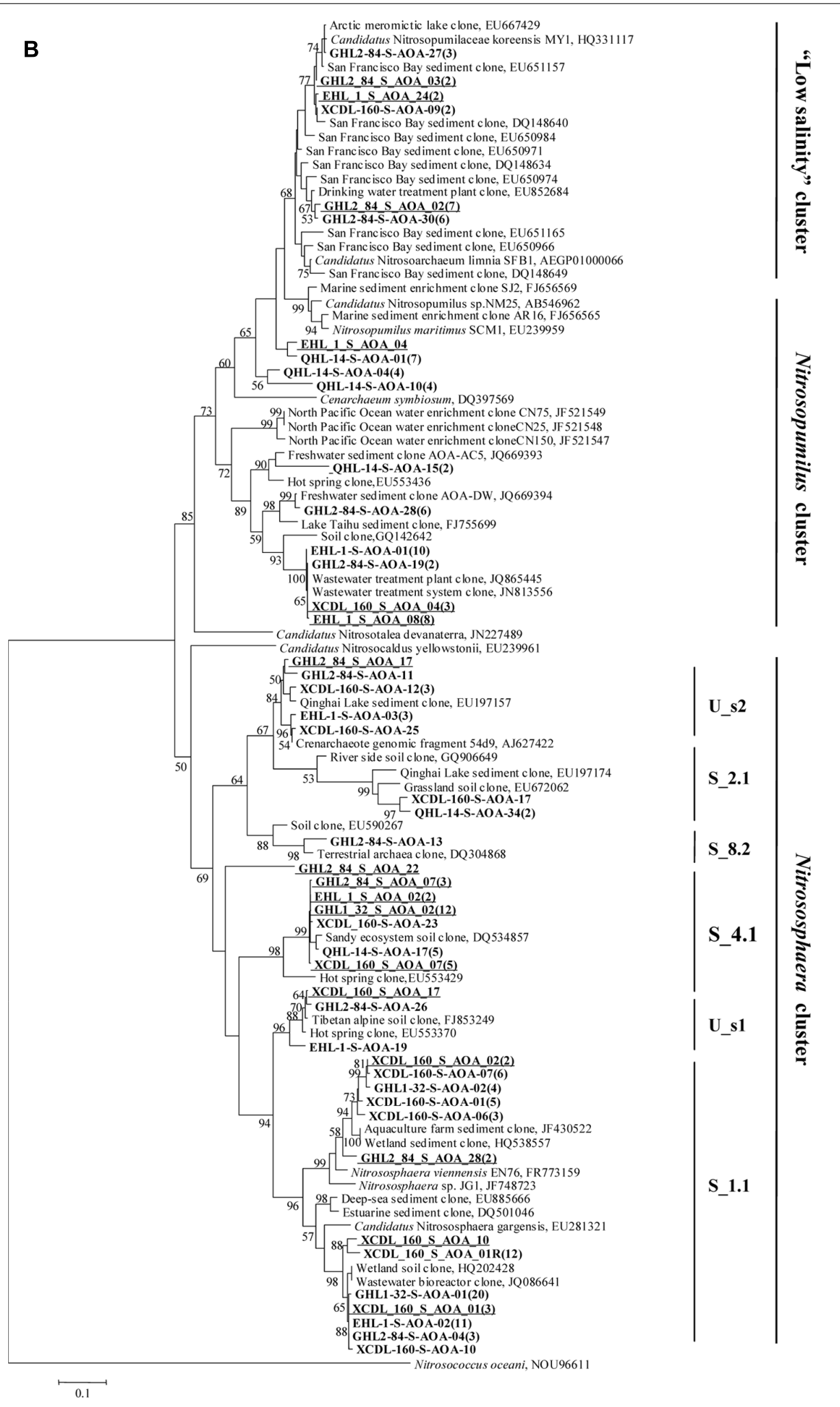

FIGURE 5 | Continued

were corresponded to QLW1-0 and QLS-30 in Jiang etal. (2009b), respectively. The " $R$ " symbol in some clone names denotes RNA-based ( $\mathrm{DDNA}$ ) clones. The underlined clone sequences were derived from the CrenamoA23f/CrenamoA616r primer set. The classification system of Pester etal. (2012) was employed. The letters "S" and " $U$ " in the cluster names indicated "subcluster" and "unclassified." The scale bars indicate the Jukes-Cantor distances. Bootstrap values of (1000 replicates) $>50 \%$ are shown. The bacterial amoA gene from Nitrosococcus oceani was used as outgroup. Panels (A) and (B) are for waters and sediments, respectively. 


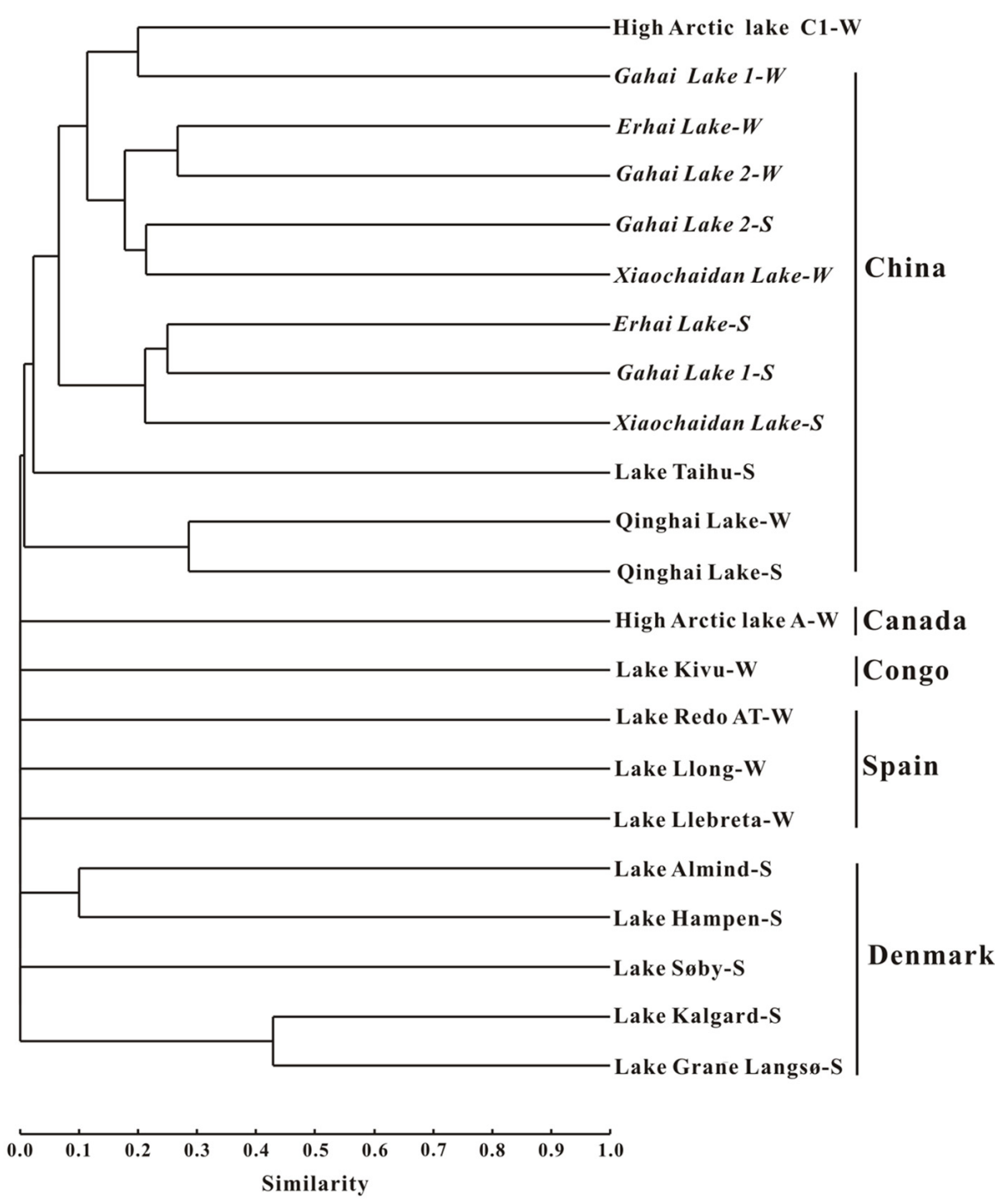

FIGURE 6 | Jaccard similarity-based cluster analysis of the amoA gene communities in different lakes worldwide. The archaeal amoA gene sequences obtained in this study were combined with those previously reported for Qinghai Lake (Jiang et al., 2009b), Lake Taihu Mu et al., 2010), high arctic lake (Pouliot etal., 2009), Lake Kivu (Llirós etal., 2010), Spanish lakes (Auguet et al., 2011), and Danish lakes (Herrmann et al., 2009). The numbers of clones from each location are given in Table 1. "W" and "S" indicate water and sediment samples, respectively. study were highly similar to one other, suggesting that unique environmental conditions (high elevation, strong ultraviolet and dry climate) of the Qinghai-Tibet Plateau may have limited the AEA community diversity in these lakes to a low level.

Many studies have suggested that AOA (Fernàndez-Guerra and Casamayor, 2012) ecological niches are affected by various environmental factors, such as dissolved oxygen (DO), temperature, and salinity (see review by Erguder et al., 2009 and references therein). In this study, salinity and other water chemistry did not have significant correlations with AEA community diversity. However, the difference was observed in the AEA communities between waters and sediments (Figure 3), suggesting that the AEA in the sediments were native, and they were not derived from the water column. This observed difference between water and sediment was consistent with previous studies (Francis et al., 2005; Beman and Francis, 2006; Jiang et al., 2009b) and may be ascribed to the fact that water and sediment are different habitats with different environmental conditions. However, with limited data, it is not realistic to identify which factor accounts for the observed difference in the amoA gene communities between water and sediments.

Furthermore, the AEA community composition in the studied Qinghai-Tibetan lakes was different from those in other lakes (Figure 6) and saline environments (Figure 7) worldwide, suggesting that the Qinghai-Tibetan lakes are a unique habitat (e.g., high elevation, strong UV exposure, and dry climate) and thus AEA in these lakes may possess different evolutionary history than their counterparts in other ecosystems. 


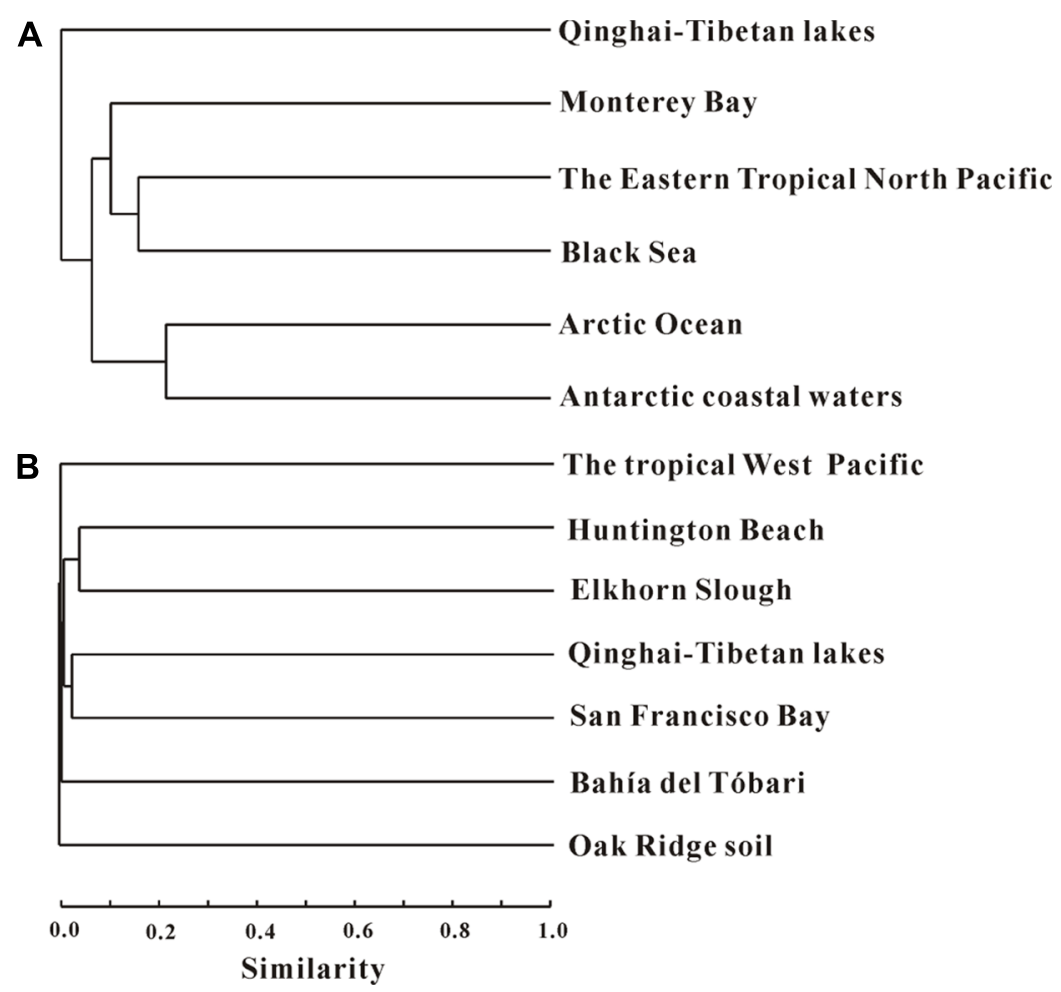

FIGURE 7 | Jaccard similarity-based cluster analysis of the amoA gene communities in different habitats worldwide. Panels (A) and (B) are for water and sediment/soil samples, respectively. (A) The archaeal amoA gene sequences obtained in this study were compared with those previously reported in the waters of Monterey Bay, the Eastern Tropical North Pacific, and the Black Sea (Francis etal., 2005), and Arctic Ocean and Antarctic coasts
(Kalanetra et al., 2009). (B) The archaeal amoA gene sequences obtained in this study were compared with those previously reported in the sediments from Elkhorn Slough, and Huntington Beach of California, Bahía del Tbóari of Mexico, and the San Francisco Bay (Francis etal., 2005), the tropical West Pacific Continental Margin (Dang et al., 2009), and an Oak Ridge soil (Francis etal., 2005). The numbers of clones from each location are given in Table 1.

\section{COMPARISON BETWEEN THE TWO PRIMER SETS FOR AEA amoA GENES}

The primer set of CrenamoA23f/CrenamoA616r was originally designed by Tourna et al. (2008) on the basis of the soil fosmid 54d9 (Treusch et al., 2005) and the Sargasso Sea data set (Venter et al., 2004). Subsequently it has been used to successfully amplify AOA amoA genes from soil samples (Tourna et al., 2008; Hallin et al., 2009; Stopnišek et al., 2010; Yao et al., 2011; Zhang et al., 2012). However, in this study higher AEA amoA gene diversity was obtained with the use of the primer set of Arch-amoAF/ArchamoAR (Francis et al., 2005). Furthermore, non-singleton OTUs derived from the CrenamoA23f/CrenamoA616r primer set were already present within the clone libraries constructed from the Arch-amoAF/Arch-amoAR primer set (Figure 5). These lines of evidence suggest that the primer set of Arch-amoAF/ArchamoAR is more appropriate than CrenamoA23f/CrenamoA616r in characterizing the AEA diversity in the Qinghai-Tibetan lakes.

\section{ACKNOWLEDGMENTS}

This research was supported by the National Natural Science Foundation of China (Grant nos. 41002123 and 41030211), State Key Laboratory of Biogeology, and Environmental Geology, China University of Geosciences (no. GBL11201), and the Fundamental
Research Funds for National University, China University of Geosciences (Wuhan). We are grateful to Jinxiang Wang at Tongji University for help with sample collection. Chuanlun Zhang acknowledges the support for the LC-MS analysis by the State Key Laboratory of Marine Geology and the "National Thousand Talents" Program at Tongji University. The authors are grateful to Dr. Brian P. Hedlund and three anonymous reviewers whose constructive comments significantly improved the quality of the manuscript.

\section{REFERENCES}

Analytical Lab of the Qinghai Institute of Salt Lakes, Chinese Academy of Sciences. (1988). Analytical Methods of Brine and Salt. Beijing: Science Press.

Auguet, J.-C., Barberan, A., and Casamayor, E. O. (2009). Global ecological patterns in uncultured Archaea. ISME J. 4, 182-190. doi: 10.1038/ismej.2009. 109

Auguet, J.-C., and Casamayor, E. O. (2013). Partitioning of Thaumarchaeota populations along environmental gradients in high mountain lakes. FEMS Microbiol. Ecol. 84, 154-164. doi: 10.1111/1574-6941.12047

Auguet, J.-C., Nomokonova, N., Camarero, L., and Casamayor, E. O. (2011). Seasonal changes of freshwater ammonia-oxidizing archaeal assemblages and nitrogen species in oligotrophic Alpine Lakes. Appl. Environ. Microbiol. 77, 1937-1945. doi: 10.1128/AEM.01213-10

Auguet, J.-C., Triado-Margarit, X., Nomokonova, N., Camarero, L., and Casamayor, E. O. (2012). Vertical segregation and phylogenetic characterization of ammoniaoxidizing Archaea in a deep oligotrophic lake. ISME J. 6, 1786-1797. doi: 10.1038/ismej.2012.33 
Bechtel, A., Smittenberg, R. H., Bernasconi, S. M., and Schubert, C. J. (2010). Distribution of branched and isoprenoid tetraether lipids in an oligotrophic and a eutrophic Swiss lake: insights into sources and GDGT-based proxies. Org. Geochem. 41, 822-832. doi: 10.1016/j.orggeochem.2010.04.022

Beman, J. M., and Francis, C. A. (2006). Diversity of ammonia-oxidizing archaea and bacteria in the sediments of a hypernutrified subtropical estuary: Bahía del Tóbari, Mexico. Appl. Environ. Microbiol. 72, 7767-7777. doi: 10.1128/AEM. 00946-06

Blaga, C., Reichart, G-J., Heiri, O., and Sinninghe Damsté, J. (2009). Tetraether membrane lipid distributions in water-column particulate matter and sediments: a study of 47 European lakes along a north-south transect. J. Paleolimnol. 41, 523-540. doi: 10.1007/s10933-008-9242-2

Blainey, P. C., Mosier, A. C., Potanina, A., Francis, C. A., and Quake, S. R. (2011). Genome of a low-salinity ammonia-oxidizing archaeon determined by single-cell and metagenomic analysis. PLOS ONE 6:e16626. doi: 10.1371/journal.pone.0016626

Bligh, E., and Dyer, W. J. (1959). A rapid method of total lipid extraction and purification. Can. J. Biochem. Physiol. 37, 911-917. doi: 10.1139/o59-099

Brochier-Armanet, C., Boussau, B., Gribaldo, S., and Forterre, P. (2008). Mesophilic crenarchaeota: proposal for a third archaeal phylum, the Thaumarchaeota. Nat. Rev. Microbiol. 6, 245-252. doi: 10.1038/nrmicro1852

Buckles, L. K., Villanueva, L., Weijers, J. W. H., Verschuren, D., and Sinninghe Damsté, J. S. (2013). Linking isoprenoidal GDGT membrane-lipid distributions with gene abundances of ammonia-oxidising Thaumarchaeota and uncultured crenarchaeotal groups in the water column of a tropical lake (Lake Challa, East Africa). Environ. Microbiol. 15, 2445-2462. doi: 10.1111/1462-2920. 12118

Castañeda, I. S., and Schouten, S. (2011). A review of molecular organic proxies for examining modern and ancient lacustrine environments. Quat. Sci. Rev. 30, 2851-2891. doi: 10.1016/j.quascirev.2011.07.009

Dang, H., Li, J., Chen, R., Wang, L., Guo, L., Zhang, Z., et al. (2010). Diversity, abundance, and spatial distribution of sediment ammonia-oxidizing betaproteobacteria in response to environmental gradients and coastal Eutrophication in Jiaozhou Bay, China. Appl. Environ. Microbiol. 76, 4691-4702. doi: 10.1128/AEM.02563-09

Dang, H., Li, J., Zhang, X., Li, T., Tian, F., and Jin, W. (2009). Diversity and spatial distribution of amoA-encoding archaea in the deep-sea sediments of the tropical West Pacific Continental Margin. J. Appl. Microbiol. 106, 1482-1493. doi: 10.1111/j.1365-2672.2008.04109.x

de la Torre, J. R., Walker, C. B., Ingalls, A. E., Könneke, M., and Stahl, D. A. (2008). Cultivation of a thermophilic ammonia oxidizing archaeon synthesizing crenarchaeol. Environ. Microbiol. 10, 810-818. doi: 10.1111/j.1462-2920.2007.01506.x

Dong, H., Jiang, H., Yu, B., Liu, X., and Chan, M. A. (2010). Impacts of environmental change and human activity on microbial ecosystems on the Tibetan Plateau, NW China. GSA Today 20, 4-10. doi: 10.1130/GSATG75A.1

Dong, H., Zhang, G., Jiang, H., Yu, B., Chapman, L., Lucas, C., et al. (2006). Microbial diversity in sediments of saline Qinghai Lake, China: linking geochemical controls to microbial ecology. Microb. Ecol. 51, 65-82. doi: 10.1007/s00248-005-0228-6

Erguder, T. H., Boon, N., Wittebolle, L., Marzorati, M., and Verstraete, W. (2009). Environmental factors shaping the ecological niches of ammoniaoxidizing archaea. FEMS Microbiol. Rev. 33, 855-869. doi: 10.1111/j.15746976.2009.00179.x

Fernàndez-Guerra, A., and Casamayor, E. O. (2012). Habitat-associated phylogenetic community patterns of microbial ammonia oxidizers. PLoS ONE 7:e47330. doi: 10.1371/journal.pone.0047330

Francis, C. A., Roberts, K. J., Beman, J. M., Santoro, A. E., and Oakley, B. B. (2005). Ubiquity and diversity of ammonia-oxidizing archaea in water columns and sediments of the ocean. Proc. Natl. Acad. Sci. U.S.A. 102, 14683-14688. doi: 10.1073/pnas.0506625102

French, E., Kozlowski, J. A., Mukherjee, M., Bullerjahn, G., and Bollmann, A. (2012a). Ecophysiological characterization of ammonia-oxidizing Archaea and bacteria from freshwater. Appl. Environ. Microbiol. 78, 5773-5780. doi: 10.1128/AEM.00432-12

French, E., Kozlowski, J. A., Mukherjee, M., Bullerjahn, G., and Bollmann, A. (2012b). Enrichment and characterization of three ammoniaoxidizing Archaea from freshwater environments. Appl. Environ. Microbiol. doi: 10.1128/aem.00432-12
Hallin, S., Jones, C. M., Schloter, M., and Philippot, L. (2009). Relationship between $\mathrm{N}$-cycling communities and ecosystem functioning in a 50-year-old fertilization experiment. ISME J. 3, 597-605. doi: 10.1038/ismej.2008.128

Hatzenpichler, R. (2012). Diversity, physiology and niche differentiation of ammonia-oxidizing archaea. Appl. Environ. Microbiol. 78, 7501-7510. doi: 10.1128/AEM.01960-12

Herrmann, M., Saunders, A. M., and Schramm, A. (2009). Effect of lake trophic status and rooted macrophytes on community composition and abundance of ammonia-oxidizing prokaryotes in freshwater sediments. Appl. Environ. Microbiol. 75, 3127-3136. doi: 10.1128/AEM.02806-08

Herrmann, M., Scheibe, A., Avrahami, S., and Küsel, K. (2011). Ammonium Availability affects the ratio of ammonia-oxidizing bacteria to ammonia-oxidizing archaea in simulated creek ecosystems. Appl. Environ. Microbiol. 77, 1896-1899. doi: 10.1128/AEM.02879-10

Hopmans, E. C., Weijers, J. W. H., Schefuß, E., Herfort, L., Sinninghe Damsté, J. S., and Schouten, S. (2004). A novel proxy for terrestrial organic matter in sediments based on branched and isoprenoid tetraether lipids. Earth Planet. Sci. Lett. 224, 107-116. doi: 10.1016/j.epsl.2004.05.012

Hu, A., Yao, T., Jiao, N., Liu, Y., Yang, Z. A. O., and Liu, X. (2010). Community structures of ammonia-oxidising archaea and bacteria in highaltitude lakes on the Tibetan Plateau. Freshwat. Biol. 55, 2375-2390. doi: 10.1111/j.1365-2427.2010.02454.x

Huang, L., Jiang, H., Wang, S., Zhang, C., and Dong, H. (2011). Structure of planktonic ammonia-oxidizing community in the waters near the Three Gorges Dam of the Yangtze River. Acta Microbiol. Sin. 51, 83-90.

Hugoni, M., Etien, S., Bourges, A., Lepère, C., Domaizon, I., Mallet, C., et al. (2013). Dynamics of ammonia-oxidizing Archaea and Bacteria in contrasted freshwater ecosystems. Res. Microbiol. 164, 360-370. doi: 10.1016/j.resmic.2013.01.004

Huguet, C., Hopmans, E. C., Febo-Ayala, W., Thompson, D. H., Sinninghe Damsté, J. S., and Schouten, S. (2006). An improved method to determine the absolute abundance of glycerol dibiphytanyl glycerol tetraether lipids. Org. Geochem. 37, 1036-1041. doi: 10.1016/j.orggeochem.2006.05.008

Jiang, H., Dong, H., Deng, S., Yu, B., Huang, Q., and Wu, Q. (2009a). Response of archaeal community structure to environmental changes in lakes on the Tibetan Plateau, northwestern China. Geomicrobiol. J. 26, 289-297. doi: 10.1080/01490450902892662

Jiang, H., Dong, H., Yu, B., Lv, G., Deng, S., Berzins, N., et al. (2009b). Diversity and abundance of ammonia-oxidizing archaea and bacteria in Qinghai Lake, Northwestern China. Geomicrobiol. J. 26, 199-211. doi: 10.1080/014904509027 44004

Jiang, H., Dong, H., Yu, B., Liu, X., Li, Y., Ji, S., et al. (2007). Microbial response to salinity change in Lake Chaka, a hypersaline lake on Tibetan plateau. Environ. Microbiol. 9, 2603-2621. doi: 10.1111/j.1462-2920.2007.01377.x

Jiang, H., Dong, H., Zhang, G., Yu, B., Chapman, L. R., and Fields, M. W. (2006). Microbial diversity in water and sediment of Lake Chaka, an athalassohaline lake in northwestern China. Appl. Environ. Microbiol. 72, 3832-3845. doi: 10.1128/AEM.02869-05

Jiang, H., Huang, Q., Deng, S., Dong, H., and Yu, B. (2010). Planktonic actinobacterial diversity along a salinity gradient of a river and five lakes on the Tibetan Plateau. Extremophiles 14, 367-376. doi: 10.1007/s00792-010-0316-5

Kalanetra, K. M., Bano, N., and Hollibaugh, J. T. (2009). Ammonia-oxidizing archaea in the Arctic Ocean and Antarctic coastal waters. Environ. Microbiol. 11, 2434-2445. doi: 10.1111/j.1462-2920.2009.01974.x

Kim, J.-H., Huguet, C., Zonneveld, K. A. F., Versteegh, G. J. M., Roeder, W., Sinninghe Damsté, J. S., et al. (2009). An experimental field study to test the stability of lipids used for the TEX86 and palaeothermometers. Geochim. Cosmochim. Acta 73, 2888-2898. doi: 10.1016/j.gca.2009.02.030

Könneke, M., Bernhard, A. E., De La Torre, J. R., Walker, C. B., Waterbury, J. B., and Stahl, D. A. (2005). Isolation of an autotrophic ammonia-oxidizing marine archaeon. Nature 437, 543-546. doi: 10.1038/nature03911

Leininger, S., Urich, T., Schloter, M., Schwark, L., Qi, J., Nicol, G. W., et al. (2006). Archaea predominate among ammonia-oxidizing prokaryotes in soils. Nature 442, 806-809. doi: 10.1038/nature04983

Liu, Y., Yao, T., Jiao, N., Zhu, L., Hu, A., Liu, X., et al. (2012). Salinity impact on bacterial community composition in five high-altitude lakes from the Tibetan plateau, Western China. Geomicrobiol. J. 30, 462-469. doi: 10.1080/01490451.2012.710709 Llirós, M., Gich, F., Plasencia, A., Auguet, J.-C., Darchambeau, F., Casamayor, E. O., et al. (2010). Vertical distribution of ammonia-oxidizing crenarchaeota 
and methanogens in the epipelagic waters of Lake Kivu (Rwanda-Democratic Republic of the Congo). Appl. Environ. Microbiol. 76, 6853-6863. doi: 10.1128/AEM.02864-09

Mosier, A. C., and Francis, C. A. (2008). Relative abundance and diversity of ammonia-oxidizing archaea and bacteria in the San Francisco Bay estuary. Environ. Microbiol. 10, 3002-3016. doi: 10.1111/j.1462-2920.2008.01764.x

Nicol, G. W., and Schleper, C. (2006). Ammonia-oxidising Crenarchaeota: important players in the nitrogen cycle? Trends Microbiol. 14, 207-212. doi: 10.1016/j.tim.2006.03.004

Oren, A. (2011). Thermodynamic limits to microbial life at high salt concentrations. Environ. Microbiol. 13, 1908-1923. doi: 10.1111/j.1462-2920.2010.02365.x

Pearson, A., Huang, Z., Ingalls, A. E., Romanek, C. S., Wiegel, J., Freeman, K. H., et al. (2004). Nonmarine Crenarchaeol in Nevada hot springs. Appl. Environ. Microbiol. 70, 5229-5237. doi: 10.1128/AEM.70.9.5229-5237.2004

Pearson, A., and Ingalls, A. E. (2013). Assessing the use of archaeal lipids as marine environmental proxies. Annu. Rev. Earth Planet. Sci. 41, 359-384. doi: 10.1146/annurev-earth-050212-123947

Pearson, A., Pi, Y., Zhao, W., Li, W., Li, Y., Inskeep, W., et al. (2008). Factors controlling the distribution of archaeal tetraethers in terrestrial hot springs. Appl. Environ. Microbiol. 74, 3523-3532. doi: 10.1128/AEM.02450-07

Pearson, E. J., Juggins, S., Talbot, H. M., Weckström, J., Rosén, P., Ryves, D. B., etal. (2011). A lacustrine GDGT-temperature calibration from the Scandinavian Arctic to Antarctic: renewed potential for the application of GDGTpaleothermometry in lakes. Geochim. Cosmochim. Acta 75, 6225-6238. doi: 10.1016/j.gca.2011.07.042

Pester, M., Rattei, T., Flechl, S., Gröngröft, A., Richter, A., Overmann, J., et al. (2012). amoA-based consensus phylogeny of ammonia-oxidizing archaea and deep sequencing of amoA genes from soils of four different geographic regions. Environ. Microbiol. 14, 525-539. doi:10.1111/j.1462-2920.2011.02666.x

Pester, M., Schleper, C., and Wagner, M. (2011). The Thaumarchaeota: an emerging view of their phylogeny and ecophysiology. Curr. Opin. Microbiol. 14, 300-306. doi: 10.1016/j.mib.2011.04.007

Pitcher, A., Hopmans, E. C., Mosier, A. C., Park, S.-J., Rhee, S.-K., Francis, C. A., et al. (2011a). Core and intact polar glycerol dibiphytanyl glycerol tetraether lipids of ammonia-oxidizing archaea enriched from marine and estuarine sediments. Appl. Environ. Microbiol. 77, 3468-3477. doi: 10.1128/AEM.02758-10

Pitcher, A., Villanueva, L., Hopmans, E. C., Schouten, S., Reichart, G.-J., and Sinninghe Damste, J. S. (2011b). Niche segregation of ammonia-oxidizing archaea and anammox bacteria in the Arabian Sea oxygen minimum zone. ISME J. 5, 1896-1904. doi: 10.1038/ismej.2011.60

Pitcher, A., Rychlik, N., Hopmans, E. C., Spieck, E., Rijpstra, W. I. C., Ossebaar, J., et al. (2010). Crenarchaeol dominates the membrane lipids of Candidatus Nitrososphaera gargensis, a thermophilic group I.1b Archaeon. ISME J. 4, 542552. doi: 10.1038/ismej.2009.138

Pitcher, A., Schouten, S., and Sinninghe Damsté, J. S. (2009). In situ production of crenarchaeol in two California hot springs. Appl. Environ. Microbiol. 75, 44434451. doi: 10.1128/AEM.02591-08

Pouliot, J., Galand, P. E., Lovejoy, C., and Vincent, W. F. (2009). Vertical structure of archaeal communities and the distribution of ammonia monooxygenase A gene variants in two meromictic High Arctic lakes. Environ. Microbiol. 11, 687-699. doi: 10.1111/j.1462-2920.2008.01846.x

Preston, C. M., Wu, K. Y., Molinski, T. F., and Delong, E. F. (1996). A psychrophilic crenarchaeon inhabits a marine sponge: Cenarchaeum symbiosum gen. nov., sp. nov. Proc. Natl. Acad. Sci. U.S.A. 93, 6241-6246. doi: 10.1073/pnas.93.13.6241

Sahan, E., and Muyzer, G. (2008). Diversity and spatio-temporal distribution of ammonia-oxidizing archaea and bacteria in sediments of the Westerschelde estuary. FEMS Microbiol. Ecol. 64, 175-186. doi: 10.1111/j.1574-6941.2008. 00462.x

Schloss, P. D., and Handelsman, J. (2005). Introducing DOTUR, a computer program for defining operational taxonomic units and estimating species richness. Appl. Environ. Microbiol. 71, 1501-1506. doi: 10.1128/AEM.71.3.1501-1506.2005

Schouten, S., Hopmans, E. C., Baas, M., Boumann, H., Standfest, S., Könneke, M., et al. (2008). Intact membrane lipids of "Candidatus nitrosopumilus maritimus," a cultivated representative of the cosmopolitan mesophilic group I Crenarchaeota. Appl. Environ. Microbiol. 74, 2433-2440. doi: 10.1128/AEM.01709-07

Schouten, S., Hopmans, E. C., and Sinninghe Damsté, J. S. (2013). The organic geochemistry of glycerol dialkyl glycerol tetraether lipids: a review. Org. Geochem. 54, 19-61. doi: 10.1016/j.orggeochem.2012.09.006
Schouten, S., Huguet, C., Hopmans, E. C., Kienhuis, M. V. M., and Sinninghe Damsté, J. S. (2007). Analytical methodology for TEX86 paleothermometry by high-performance liquid chromatography/atmospheric pressure chemical ionization-mass spectrometry. Anal. Chem. 79, 2940-2944. doi: $10.1021 / \mathrm{ac} 062339 \mathrm{v}$

Schouten, S., Middelburg, J. J., Hopmans, E. C., and Sinninghe Damsté, J. S. (2010). Fossilization and degradation of intact polar lipids in deep subsurface sediments: a theoretical approach. Geochim. Cosmochim. Acta 74, 3806-3814. doi: 10.1016/j.gca.2010.03.029

Sinninghe Damsté, J. S., Ossebaar, J., Abbas, B., Schouten, S., and Verschuren, D. (2009). Fluxes and distribution of tetraether lipids in an equatorial African lake: constraints on the application of the TEX86 palaeothermometer and BIT index in lacustrine settings. Geochim. Cosmochim. Acta 73, 4232-4249. doi: 10.1016/j.gca.2009.04.022

Sinninghe Damsté, J. S., Rijpstra, W. I. C., Hopmans, E. C., Jung, M.-Y., Kim, J.G., Rhee, S.-K., et al. (2012). Intact polar and core glycerol dibiphytanyl glycerol tetraether lipids of group I.1a and I.1b Thaumarchaeota in soil. Appl. Environ. Microbiol. 78, 6866-6874. doi: 10.1128/AEM.01681-12

Sinninghe Damsté, J. S., Schouten, S., Hopmans, E. C., Van Duin, A. C. T., and Geenevasen, J. A. J. (2002). Crenarchaeol: the characteristic core glycerol dibiphytanyl glycerol tetraether membrane lipid of cosmopolitan pelagic crenarchaeota. J. Lipid Res. 43, 1641-1651. doi: 10.1194/jlr.M200148-JLR200

Spang, A., Hatzenpichler, R., Brochier-Armanet, C., Rattei, T., Tischler, P., Spieck, E., et al. (2010). Distinct gene set in two different lineages of ammonia-oxidizing archaea supports the phylum Thaumarchaeota. Trends Microbiol. 18, 331-340. doi: 10.1016/j.tim.2010.06.003

Stahl, D. A., and de la Torre, J. R. (2012). Physiology and diversity of ammoniaoxidizing archaea. Annu. Rev. Microbiol. 66, 83-101. doi: 10.1146/annurev-micro092611-150128

Stopnišek, N., Gubry-Rangin, C., Höfferle, Š., Nicol, G. W., Mandič-Mulec, I., and Prosser, J. I. (2010). Thaumarchaeal ammonia oxidation in an acidic forest peat soil is not influenced by ammonium amendment. Appl. Environ. Microbiol. 76, 7626-7634. doi: 10.1128/AEM.00595-10

Takai, K., and Horikoshi, K. (2000). Rapid detection and quantification of members of the archaeal community by quantitative PCR using fluorogenic probes. Appl. Environ. Microbiol. 66, 5066-5072. doi: 10.1128/AEM.66.11.5066-5072. 2000

Tamura, K., Peterson, D., Peterson, N., Stecher, G., Nei, M., and Kumar, S. (2011). MEGA5: molecular evolutionary genetics analysis using maximum likelihood, evolutionary distance, and maximum parsimony methods. Mol. Biol. Evol. 28, 2731-2739. doi: 10.1093/molbev/msr121

Tierney, J. E., Russell, J. M., Eggermont, H., Hopmans, E. C., Verschuren, D., and Sinninghe Damsté, J. S. (2010). Environmental controls on branched tetraether lipid distributions in tropical East African lake sediments. Geochim. Cosmochim. Acta 74, 4902-4918. doi: 10.1016/j.gca.2010.06.002

Tourna, M., Freitag, T. E., Nicol, G. W., and Prosser, J. I. (2008). Growth, activity and temperature responses of ammonia-oxidizing archaea and bacteria in soil microcosms. Environ. Microbiol. 10, 1357-1364. doi: 10.1111/j.1462-2920.2007.01563.x Tourna, M., Stieglmeier, M., Spang, A., Könneke, M., Schintlmeister, A., Urich, T., et al. (2011). Nitrososphaera viennensis, an ammonia oxidizing archaeon from soil. Proc. Natl. Acad. Sci. U.S.A. 108, 8420-8425. doi: 10.1073/pnas.1013488108

Treusch, A. H., Leininger, S., Kletzin, A., Schuster, S. C., Klenk, H.-P., and Schleper, C. (2005). Novel genes for nitrite reductase and Amo-related proteins indicate a role of uncultivated mesophilic crenarchaeota in nitrogen cycling. Environ. Microbiol. 7, 1985-1995. doi: 10.1111/j.1462-2920.2005.00906.x

van der Wielen, P. W. J. J., Voost, S., and Van Der Kooij, D. (2009). Ammonia-oxidizing bacteria and archaea in groundwater treatment and drinking water distribution systems. Appl. Environ. Microbiol. 75, 4687-4695. doi: 10.1128/AEM.00387-09

Venter, J. C., Remington, K., Heidelberg, J. F., Halpern, A. L., Rusch, D., Eisen, J. A., et al. (2004). Environmental genome shotgun sequencing of the Sargasso Sea. Science 304, 66-74. doi: 10.1126/science.1093857

Vissers, E. W., Blaga, C. I., Bodelier, P. L. E., Muyzer, G., Schleper, C., Sinninghe Damsté, J. S., et al. (2013). Seasonal and vertical distribution of putative ammonia-oxidizing thaumarchaeotal communities in an oligotrophic lake. FEMS Microbiol. Ecol. 83, 515-526. doi: 10.1111/1574-6941.12013

Wang, H., Liu, W., Zhang, C. L., Jiang, H., Dong, H., Lu, H., et al. (2013). Assessing the ratio of archaeol to caldarchaeol as a salinity proxy in highland lakes 
on the northeastern Qinghai-Tibetan Plateau. Org. Geochem. 54, 69-77. doi: 10.1016/j.orggeochem.2012.09.011

Wang, S., Wang, Y., Feng, X., Zhai, L., and Zhu, G. (2011). Quantitative analyses of ammonia-oxidizing Archaea and bacteria in the sediments of four nitrogen-rich wetlands in China. Appl. Microbiol. Biotechnol. 90, 779-787. doi: 10.1007/s00253011-3090-0

Wang, S. M., and Dou, H. S. (1998). Lakes in China (in Chinese). Beijing: Science Press.

Wang, Y., Zhu, G., Ye, L., Feng, X., Op Den Camp, H. J. M., and Yin, C. (2012). Spatial distribution of archaeal and bacterial ammonia oxidizers in the littoral buffer zone of a nitrogen-rich lake. J. Environ. Sci. 24, 790-799. doi: 10.1016/S10010742(11)60861-9

Weijers, J. W. H., Schouten, S., Spaargaren, O. C., and Sinninghe Damsté, J. S. (2006). Occurrence and distribution of tetraether membrane lipids in soils: implications for the use of the TEX86 proxy and the BIT index. Org. Geochem. 37, 1680-1693. doi: 10.1016/j.orggeochem.2006.07.018

Wu, Q. L., Zwart, G., Schauer, M., Kamst-Van Agterveld, M. P., and Hahn, M. W. (2006). Bacterioplankton community composition along a salinity gradient of sixteen high-mountain lakes located on the Tibetan plateau, China. Appl. Environ. Microbiol. 72, 5478-5485. doi: 10.1128/AEM.00767-06

Wu, Y., Xiang, Y., Wang, J., Zhong, J., He, J., and Wu, Q. L. (2010). Heterogeneity of archaeal and bacterial ammonia-oxidizing communities in Lake Taihu, China. Environ. Microbiol. Rep. 2, 569-576. doi: 10.1111/j.1758-2229.2010.00146.x

Xiong, J., Liu, Y., Lin, X., Zhang, H., Zeng, J., Hou, J., et al. (2012). Geographic distance and $\mathrm{pH}$ drive bacterial distribution in alkaline lake sediments across Tibetan plateau. Environ. Microbiol. 14, 2457-2466. doi: 10.1111/j.14622920.2012.02799.x

Yang, J., Jiang, H., Dong, H., Wu, G., Hou, W., Zhao, W., et al. (2013). Diversity of carbon monoxide-oxidizing bacteria in five lakes on the Qinghai-Tibet Plateau, China. Geomicrobiol. J. 30, 758-767. doi: 10.1080/01490451.2013.769652

Yang, J., Jiang, H., Wu, G., Hou, W., Sun, Y., Lai, Z., et al. (2012). Co-occurrence of nitrite-dependent anaerobic methane oxidizing and anaerobic ammonia oxidizing bacteria in two Qinghai-Tibetan saline lakes. Front. Earth Sci. 6, 383-391. doi: 10.1007/s11707-012-0336-9

Yang, X., Wang, S., Kamenik, C., Schmidt, R., Shen, J., Zhu, L., et al. (2004). Diatom assemblages and quantitative reconstruction for paleosalinity from a sediment core of Chencuo Lake, southern Tibet. Sci. China Ser. D: Earth Sci. 47, 522-528. doi: $10.1360 / 02 y d 0142$
Yao, H., Gao, Y., Nicol, G. W., Campbell, C. D., Prosser, J. I., Zhang, L., et al. (2011). Links between ammonia oxidizer community structure, abundance, and nitrification potential in acidic soils. Appl. Environ. Microbiol. 77, 4618-4625. doi: 10.1128/AEM.00136-11

Zhang, C. L., Pearson, A., Li, Y.-L., Mills, G., and Wiegel, J. (2006). Thermophilic temperature optimum for crenarchaeol synthesis and its implication for archaeal evolution. Appl. Environ. Microbiol. 72, 4419-4422. doi: 10.1128/AEM.00 191-06

Zhang, C. L., Wang, J., Wei, Y., Zhu, C., Huang, L., and Dong, H. (2011). Production of branched tetraether lipids in the lower Pearl River and estuary: effects of extraction methods and impact on bGDGT proxies. Front. Microbiol. 2:274. doi: 10.3389/fmicb.2011.00274

Zhang, L.-M., Hu, H.-W., Shen, J.-P., and He, J.-Z. (2012). Ammoniaoxidizing archaea have more important role than ammonia-oxidizing bacteria in ammonia oxidation of strongly acidic soils. ISME J. 6, 1032-1045. doi: 10.1038/ismej.2011.168

Zhang, L.-M., Wang, M., Prosser, J. I., Zheng, Y.-M., and He, J.-Z. (2009). Altitude ammonia-oxidizing bacteria and archaea in soils of Mount Everest. FEMS Microbiol. Ecol. 70, 208-217. doi: 10.1111/j.1574-6941.2009.00775.x

Conflict of Interest Statement: The authors declare that the research was conducted in the absence of any commercial or financial relationships that could be construed as a potential conflict of interest.

Received: 19 May 2013; accepted: 17 October 2013; published online: 12 November 2013.

Citation: Yang J, Jiang H, Dong H, Wang H, Wu G, Hou W, Liu W, Zhang C, Sun $Y$ and Lai Z (2013) amoA-encoding archaea and thaumarchaeol in the lakes on the northeastern Qinghai-Tibetan Plateau, China. Front. Microbiol. 4:329. doi: 10.3389/fmicb.2013.00329

This article was submitted to Terrestrial Microbiology, a section of the journal Frontiers in Microbiology.

Copyright (c) 2013 Yang, Jiang, Dong, Wang, Wu, Hou, Liu, Zhang, Sun and Lai. This is an open-access article distributed under the terms of the Creative Commons Attribution License (CC BY). The use, distribution or reproduction in other forums is permitted, provided the original author(s) or licensor are credited and that the original publication in this journal is cited, in accordance with accepted academic practice. No use, distribution or reproduction is permitted which does not comply with these terms. 